Research papers

\title{
Carbon dioxide degassing at the groundwater-stream-atmosphere interface: isotopic equilibration and hydrological mass balance in a sandy watershed
}

\author{
Loris Deirmendjian ${ }^{a}$, Gwenaël Abril ${ }^{\mathrm{a}, \mathrm{b}, *}$

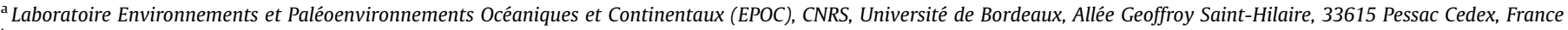 \\ ${ }^{\mathrm{b}}$ Departamento de Geoquímica, Universidade Federal Fluminense, Outeiro São João Batista s/n, 24020015 Niterói, RJ, Brazil
}

\section{A R T I C L E I N F O}

\section{Article history:}

Received 18 April 2017

Received in revised form 13 November 2017

Accepted 1 January 2018

Available online 12 January 2018

This manuscript was handled by L. Charlet,

Editor-in-Chief, with the assistance of

Philippe Negrel, Associate Editor

\section{Keywords:}

Groundwater-stream interface

Headwaters

Carbon stable isotopes $\left(\delta^{13} \mathrm{C}\right.$-DIC $)$

$\mathrm{CO}_{2}$ degassing

Carbonate weathering

\begin{abstract}
A B S T R A C T
Streams and rivers emit significant amounts of $\mathrm{CO}_{2}$ and constitute a preferential pathway of carbon transport from terrestrial ecosystems to the atmosphere. However, the estimation of $\mathrm{CO}_{2}$ degassing based on the water-air $\mathrm{CO}_{2}$ gradient, gas transfer velocity and stream surface area is subject to large uncertainties. Furthermore, the stable isotope signature of dissolved inorganic carbon $\left(\delta^{13} \mathrm{C}\right.$-DIC $)$ in streams is strongly impacted by gas exchange, which makes it a useful tracer of $\mathrm{CO}_{2}$ degassing under specific conditions. For this study, we characterized the annual transfers of dissolved inorganic carbon (DIC) along the groundwater-stream-river continuum based on DIC concentrations, stable isotope composition and measurements of stream discharges. We selected a homogeneous, forested and sandy lowland watershed as a study site, where the hydrology occurs almost exclusively through drainage of shallow groundwater (no surface runoff). We observed the first general spatial pattern of decreases in $\mathrm{pCO}_{2}$ and DIC and an increase in $\delta^{13} \mathrm{C}$-DIC from groundwater to stream orders 1 and 2, which was due to the experimentally verified faster degassing of groundwater ${ }^{12} \mathrm{C}$-DIC compared to ${ }^{13} \mathrm{C}$-DIC. This downstream enrichment in ${ }^{13} \mathrm{C}$-DIC could be modelled by simply considering the isotopic equilibration of groundwater-derived DIC with the atmosphere during $\mathrm{CO}_{2}$ degassing. A second spatial pattern occurred between stream orders 2 and 4 , consisting of an increase in the proportion of carbonate alkalinity to the DIC accompanied by the enrichment of ${ }^{13} \mathrm{C}$ in the stream DIC, which was due to the occurrence of carbonate rock weathering downstream. We could separate the contribution of these two processes (gas exchange and carbonate weathering) in the stable isotope budget of the river network. Thereafter, we built a hydrological mass balance based on drainages and the relative contribution of groundwater in streams of increasing order. After combining with the dissolved $\mathrm{CO}_{2}$ concentrations, we quantified $\mathrm{CO}_{2}$ degassing for each stream order for the whole watershed. Approximately $75 \%$ of the total $\mathrm{CO}_{2}$ degassing from the watershed occurred in first- and second-order streams. Furthermore, from stream order 2-4, our $\mathrm{CO}_{2}$ degassing fluxes compared well with those based on stream hydraulic geometry, water $\mathrm{pCO}_{2}$, gas transfer velocity, and stream surface area. In first-order streams, however, our approach showed $\mathrm{CO}_{2}$ fluxes that were twice as large, suggesting that a fraction of degassing occurred as hotspots in the vicinity of groundwater resurgence and was missed by conventional stream sampling.
\end{abstract}

(c) 2018 Elsevier B.V. All rights reserved.

\section{Introduction}

River networks have been recognized as important components of the global carbon cycle. Indeed, world rivers transport $0.9 \mathrm{Pg} \mathrm{C}$ annually from the continent to the ocean (Cole et al., 2007). This

\footnotetext{
* Corresponding author at: Laboratoire d'Océanographie et du Climat, Expérimentations et Approches Numériques (LOCEAN), Centre IRD France-Nord, 32 Avenue Henri Varagnat, F-93143 Bondy, France.

E-mail address: g.abril@u-bordeaux.fr (G. Abril).
}

number is based on a carbon concentration at various river mouths worldwide (Degens et al., 1991; Ludwig et al., 1998; Stallard, 1998; Amiotte-Suchet et al., 2003) and a direct contribution of groundwater discharge to the ocean and corresponds to the global continental C input to estuarine and coastal systems (Borges, 2005). However, streams, lakes and rivers not only act as a passive pipe delivering terrestrial carbon to the ocean but also as sites of $\mathrm{CO}_{2}$ evasion to the atmosphere (Cole and Caraco, 2001; Cole et al., 2007). Indeed, riverine waters are generally supersaturated by $\mathrm{CO}_{2}$ compared to the overlying atmosphere, and this water-air gra- 
dient leads to $\mathrm{CO}_{2}$ degassing (Frankignoulle et al., 1996; Cole et al. 2007). At the global scale, a recent estimate of $\mathrm{CO}_{2}$ degassing in streams and rivers was $1.8 \mathrm{Pg} \mathrm{C} \mathrm{yr}^{-1}$ (Raymond et al., 2013) and approximately one-third of the global $\mathrm{CO}_{2}$ degassing occurred in stream orders 1-3 (Marx et al., 2017). However, the latter studies used the Glorich database (Hartmann et al. 2014) and thus calculated $\mathrm{pCO}_{2}$ from $\mathrm{pH}$, alkalinity and temperature. As a consequence, the $\mathrm{CO}_{2}$ degassing estimation is probably overestimated, notably in low, buffered and high DOC waters such as boreal and tropical rivers, which strongly contribute to the global $\mathrm{CO}_{2}$ degassing (Abril et al., 2015). Furthermore, $\mathrm{CO}_{2}$ degassing is mostly estimated from the water-air $\mathrm{CO}_{2}$ gradient, gas transfer velocity and stream surface areas. However, at the global scale, accounting for the spatial variability of the gas transfer velocity (Raymond et al., 2012) and stream surface areas (Downing et al., 2012) are subject to large uncertainties. At the global scale, the degassing flux is of the same order of magnitude as the net $\mathrm{CO}_{2}$ uptake by the terrestrial biosphere (Ciais et al., 2013). In addition, the amount of carbon that originally leaves the terrestrial biosphere is much larger than the amount of terrestrial carbon that ultimately reaches the ocean (Cole et al., 2007).

The $\mathrm{CO}_{2}$ dissolved in riverine waters originates from two different sources and processes (Hotchkiss et al., 2015): (1) internal, i.e., resulting from heterotrophic decomposition (e.g., Hall et al., 2016) and photooxidation (e.g., Moody and Worrall, 2016) of organic matter in the aquatic system itself, or (2) external, i.e., resulting from inputs of groundwater enriched in $\mathrm{CO}_{2}$, which comes from plant root and microbial respiration of terrestrial organic matter in soils and groundwater. However, sources of and processes controlling $\mathrm{CO}_{2}$ emissions change with the size of streams and rivers (Hotchkiss et al., 2015). In headwaters (small streams), degassing is mainly of external origin and thus largely dependent on groundwater inputs and the catchment characteristics including lithology, topography, soil types, climate and vegetation (Lauerwald et al., 2013; Polsenaere et al., 2013). As stream orders and river discharge increase, soil and groundwater $\mathrm{CO}_{2}$ inputs become less significant compared to internal $\mathrm{CO}_{2}$ production. Hence, in larger rivers, internal processes become a more significant source of $\mathrm{CO}_{2}$ degassing (Hotchkiss et al., 2015), but still based on terrestrial organic carbon losses (Cole and Caraco, 2001). Moreover, several studies on headwaters have been conducted in temperate (Butman and Raymond, 2011; Polsenaere and Abril 2012), boreal (Wallin et al., 2013; Kokic et al., 2015) and tropical (Johnson et al., 2008; Davidson et al., 2010) ecosystems at different spatial scales. These works came to the same conclusion that headwaters are hotspots of $\mathrm{CO}_{2}$ degassing, i.e., as regions that exhibit disproportionately high reaction rates, relative to the surrounding area (Vidon et al., 2010). However, this hotspot character makes precise quantification of $\mathrm{CO}_{2}$ evasion difficult based on the water-air $\mathrm{CO}_{2}$ gradient, gas transfer velocity and water surface area. Indeed, the two latter parameters are sometimes difficult to quantify and subject to uncertainties at the regional scale (Downing et al., 2012; Raymond et al., 2012)

Dissolved inorganic carbon (DIC) in river systems includes not only dissolved $\mathrm{CO}_{2}\left(\mathrm{CO}_{2}^{*}\right)$ but also carbonate $\left(\mathrm{HCO}_{3}^{-}\right)$and bicarbonate ions $\left(\mathrm{CO}_{3}^{2-}\right)$, generally quantified by alkalinity titrations assuming that total alkalinity (TA) is the majority of carbonate alkalinity. TA originates from atmospheric $\mathrm{CO}_{2}$ through the weathering of carbonates, silicates and other rocks (Meybeck, 1987; Amiotte-Suchet et al., 2003; Cai et al., 2008). The stable isotope composition of DIC $\left(\delta^{13} \mathrm{C}\right.$-DIC) is controlled by both the signature of the carbon sources and the in-stream fractionating processes that change the $\delta^{13} \mathrm{C}$ signature downstream (Brunet et al., 2005; Doctor et al., 2008; Polsenaere and Abril, 2012). On the one hand, oxidation of terrestrial organic matter liberates DIC with a quite negative $\delta^{13} \mathrm{C}$ signal, close to that of the dominating plants and soils in the watershed, i.e., between -22 and $-34 \%$ for $C_{3}$ plants and -12 to $-16 \%$ or
C 4 plants (O'Leary, 1988; Vogel et al., 1993; Diefendorf et al., 2010; Kohn, 2010). In addition, due to selective molecular diffusion of $\mathrm{CO}_{2}$ through the soil pores, the isotopic composition of soil $\mathrm{CO}_{2}$ can become enriched in ${ }^{13} \mathrm{C}$ relative to soil organic matter (SOM) by up to 4-5\%o (Cerling et al., 1991; Amundson et al., 1998). On the other hand, the weathering of carbonate rocks and minerals, which have a $\delta^{13} \mathrm{C}$ of approximately $0 \%$ (Clark and Fritz, 1997), makes the $\delta^{13} \mathrm{C}$ value of DIC less negative. In addition, gas exchange along river courses increases the $\delta^{13} \mathrm{C}$ signal of DIC downstream because the atmospheric $\mathrm{CO}_{2}$ has a $\delta^{13} \mathrm{C}$ value of approximately $-8 \%$ (Doctor et al., 2008), making degassing of ${ }^{12} \mathrm{CO}_{2}$ faster than that of ${ }^{13} \mathrm{CO}_{2}$ (Polsenaere and Abril, 2012; Venkiteswaran et al., 2014). Thus, in aquatic systems with a limited amount of well-identified carbon sources and where fractionation factors can be calculated as the case for gas exchange and isotopic carbonate equilibrium, the origin and cycling of riverine DIC can be traced using $\delta^{13} \mathrm{C}$ DIC. In the case of headwaters, the isotopic signature of DIC is particularly useful, as it is governed by three major processes: the input of ${ }^{13} \mathrm{C}$-depleted carbon from soils mostly as dissolved $\mathrm{CO}_{2}$, eventually some inputs of ${ }^{13} \mathrm{C}$-enriched carbon from carbonate weathering in the form of alkalinity, and isotopic equilibration with the atmosphere induced by gas exchange (Polsenaere and Abril, 2012; Venkiteswaran et al., 2014).

In this study, we first focus on the link between $\mathrm{CO}_{2}$ degassing and the isotopic signature of DIC along the groundwater-streamriver continuum. We selected as study site a small lowland temperate catchment, which offers the convenience of low slopes, a relatively homogeneous lithology (sands) and vegetation (pine forest), as well as simple hydrological functioning, mainly in the form of shallow groundwater drainage (no surface runoff). We coupled isotopic models with experimental and in situ measurements to understand the dynamics of $\mathrm{CO}_{2}$ degassing at two different scales (groundwater-stream interface and watershed). Our isotopic model quantitatively explains the relative importance of isotopic equilibration with the atmosphere, as well as the soil and carbonate rock contributions to the DIC along the river continuum. To the best of our knowledge, this method is fully original. We demonstrate that when drainage predominates, groundwater and stream sampling can be coupled to discharge measurements to quantify $\mathrm{CO}_{2}$ degassing. This avoids the necessity of assuming or measuring a gas transfer velocity and a water surface area, two parameters that are difficult to quantify and are subject to large variability at regional and global scales.

\section{Materials and methods}

\subsection{Study site}

The Leyre watershed is located in the southwestern part of France near Bordeaux and has a surface area of $2,100 \mathrm{~km}^{2}$. The Leyre River flows $115 \mathrm{~km}$ northwest before reaching Arcachon Bay (Fig. 1). The Leyre catchment is a very flat, coastal plain with a mean slope lower than $1.25 \%$ and a mean altitude lower than $50 \mathrm{~m}$ (Jolivet et al., 2007). The lithology is relatively homogeneous and composed of different sandy permeable surface layers dating from the Plio-Quaternary Epoch (Legigan, 1979; Bertran et al., 2009, Bertran et al., 2011) (Fig. 1). However, some deep layers and outcrops are sandy carbonates (dating from the Miocene Epoch) and are locally present (Fig. 1).

The region was a vast wetland until the 19th century when a wide forest of maritime pine (Pinus pinaster) was sown following landscape drainage in 1850. Currently, the catchment is occupied mainly by pine forest (approximately $84 \%$ ), with a modest proportion of croplands (approximately 14\%). The climate is oceanic with a mean annual air temperature of $13^{\circ} \mathrm{C}$ and a mean annual precip- 


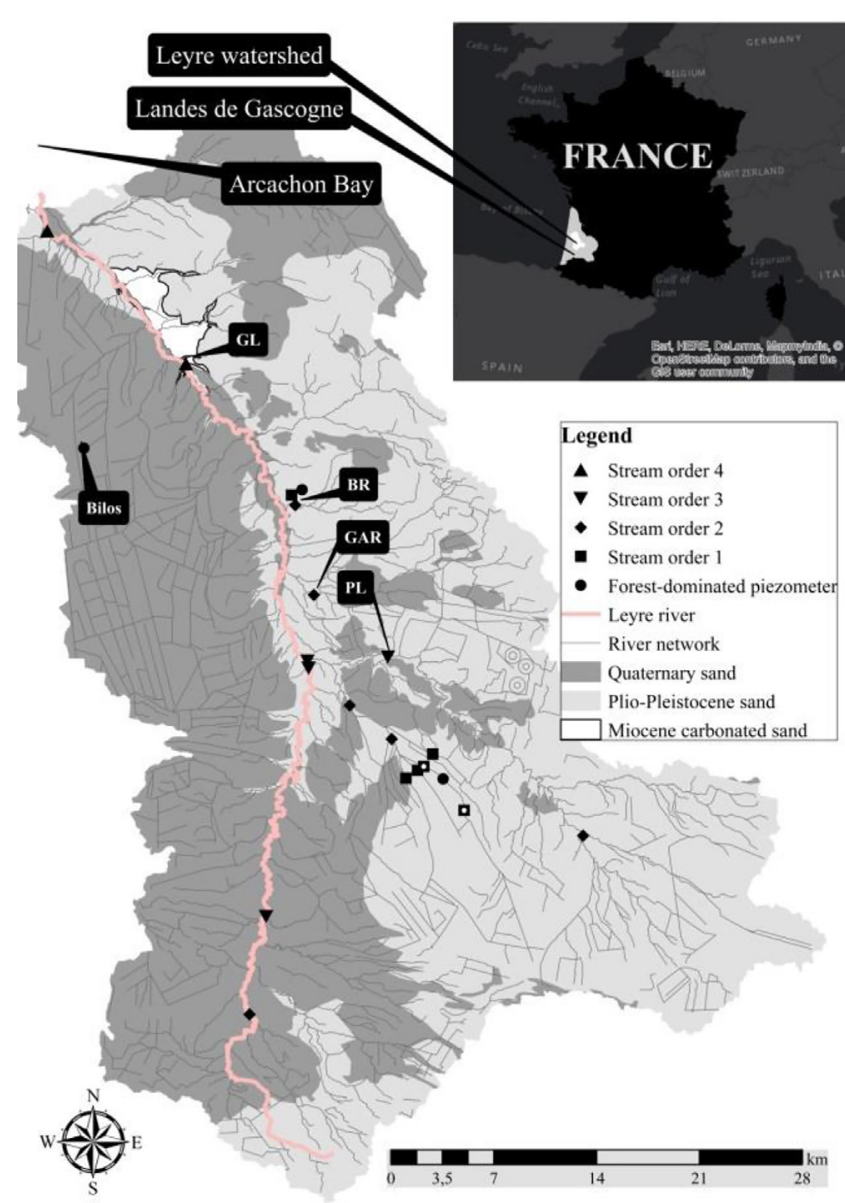

Fig. 1. Map of the Leyre watershed showing the river network, the lithology and the locations of groundwater and surface waters sampling and gauging stations. Gauging stations are all also sampling stations. GL, PL, GAR, BR are respectively the Grande Leyre, the Petite Leyre, the Grand Arriou, the Bourron gauging stations of DIREN (French water survey agency). The two first order streams with a white circle are the first order streams where discharge measurements have been made in Apr. 2014 and Feb. 2015. Bilos is the forest plot where is located the piezometer instrumented for water table depth measurement.

itation of $930 \mathrm{~mm}$ (Moreaux et al., 2011). Moreover, the average annual evapotranspiration is in the range of 234-570 and 63$800 \mathrm{~mm}$, respectively, for maritime pine and cropland (Govind et al., 2012). Owing to the low slope and the high permeability of the soil (the hydraulic conductivity is approximately $40 \mathrm{~cm} \mathrm{~h}^{-1}$, Corbier et al., 2010), the infiltration of rain water is fast (approximately $50-60 \mathrm{~cm} \mathrm{~h}^{-1}$ on average, Vernier and Castro, 2010), and thus surface runoff cannot occur, as the excess of rainfall percolates into the soil and fuels the shallow groundwater, causing the water table to rise.

The soil permeability, vegetation and climate turn the soils into podzols with an extremely coarse texture (Augusto et al., 2010). These podzols are characterized by a low $\mathrm{pH}(\sim 4)$, low organic nutrient availability, and high organic carbon content that can reach $55 \mathrm{~g}$ per $\mathrm{kg}$ of soil (Augusto et al., 2010).

The sandy permeable surface layers contain a free and continuous water table that is strongly interconnected with the superficial river network; this is facilitated by a dense network of drainage ditches, initiated in the 19th century and currently maintained by forest managers in order to increase tree growth (ThivolleCazat and Najar, 2001). The seasonal changes in the groundwater table can be important, with a water table close to the surface during wet winters and levelling down to $2.0 \mathrm{~m}$ below the surface dur- ing most summers (Augusto et al., 2010). The groundwater table is also characterized by a period of discharge (i.e., when the groundwater level decreases) and a period of reload (i.e., when the groundwater level increases). To categorize the catchment hydrology, we used a slightly modified Strahler classification method. We defined order 0 as groundwater and order 1 as streams and ditches, either having no tributaries or being seasonally dry (from June to November during our sampling period). With these definitions, the stream orders in the Leyre watershed range from 0 (groundwater) to 4 (main river). In addition, the hydrology is characterized by a period of highest flow in winter, with a flood peak usually in February or March and a period of lowest flow in spring, summer and autumn.

\subsection{Sampling strategy and field work}

\subsubsection{Selection and characterization of stations}

We selected 21 sampling stations (18 river stations and 3 piezometers) within the watershed, from groundwater (order 0 ) to stream order 4 (main stem), after precise characterization of the drainage basin within a geographical information system (Fig. 1; Table 1). We included the land use from the CORINE Land Cover (2006) database (EEA, 2014) in the GIS, as well as the hydrological superficial network as a polyline form on an open water database: the BD CARTHAGE ${ }^{\circledR}$ (www.ign.fr). The BD CARTHAGE ${ }^{\circledR}$ enables the precise determination of the length of all streams in the watershed (Table 1). Based on a digital elevation model (DEM) provided by the French Geographic Institute (IGN), we divided the Leyre watershed into subwatersheds and we calculated their respective surface areas using ArcGIS 10.2 ${ }^{\mathrm{TM}}$ (Fig. 1; Table 1). The combination (with spatial analyst extension) of the DEM and the river network (transformed into a form point shapefile beforehand) enabled us to assign an altitude to each river point and thus to determinate the mean slope $(\mathrm{S})$ per stream order (Table 1 ). We made one river width measurement per campaign for each studied station with either a decametre or a laser rangefinder (Table 1). We also sampled one groundwater spring and its respective headwaters $40 \mathrm{~m}$ downstream from the spring. All selected stations in stream orders $1-4$ have a subwatershed occupied by $80-100 \%$ pine forest $\left(C_{3}\right.$ plants) (Table 1 ), which limits the biogeochemical signal from the water that has been in contact with crops ( $C_{4}$ plants).

Concerning river discharge and depth, our study benefited from four calibrated gauging stations of DIREN (French water survey agency) with a daily temporal resolution for river discharge and with an one-hour time resolution for depth, located on two second-order streams (the Grand Arriou (GAR) and the Bourron $(\mathrm{BR})$ ), one third-order stream (the Petite Leyre (PL)) and one fourth-order stream (the Grande Leyre (GL)) (Fig. 1; Tables 1 and 2 ). For each stream order, we calculated the drainage and the drainage enrichment (DE) with a daily temporal resolution for a two year period (Table 2). The parameter DE is the ratio between two stream drainages (i.e., discharge divided by the corresponding catchment area, in $\mathrm{m}^{3} \mathrm{~km}^{-2} \mathrm{~d}^{-1}$ ) of successive orders (Table 2). Because no gauging stations were available in the first-order streams, we completed our hydrological dataset by performing river flow measurements on two first-order streams at high flow (Feb. 2016) and at base flow (Apr. 2015) (Table 2). In these first order streams, we measured water velocity profiles in a river section with a magnetic induction current metre (OTT MF pro $^{\mathrm{TM}}$ ), and we integrated the water velocity profiles in order to convert water velocity to discharge. As there is no surface runoff in the Leyre watershed, the increase in drainage (hence the drainage enrichment is $>1$ ) between two streams of successive order enables a very precise quantification of the additional diffusive groundwater inputs (Table 2).To fully characterize the stream geometry in the Leyre watershed, we used the hydraulic equations described in 
Table 1

Characteristics of the Leyre watershed and sampling network.

\begin{tabular}{|c|c|c|c|c|c|}
\hline Stream orders & $0^{*}$ & 1 & 2 & 3 & 4 \\
\hline Number of streams in the whole watershed ${ }^{a}$ & & 619 & 69 & 2 & 1 \\
\hline Cumulated river length for the whole watershed $(\mathrm{km})$ & & 1,610 & 750 & 115 & 40 \\
\hline Cumulated river flow $\left(\mathrm{m}^{3} \mathrm{~s}^{-1}\right)$ & & $9.2 \pm 2.6$ & $16.8 \pm 5.0$ & $20.2 \pm 2.8$ & 21.3 \\
\hline Mean river flow $\left(\mathrm{m}^{3} \mathrm{~s}^{-1}\right)$ & & $0.01 \pm 0.004$ & $0.24 \pm 0.07$ & $10.1 \pm 1.4$ & 21.3 \\
\hline $\operatorname{Depth}^{\mathrm{d}}(\mathrm{m})$ & & $0.12 \pm 0.03$ & $0.27 \pm 0.08$ & $0.78 \pm 0.11$ & $0.97 \pm 0.14$ \\
\hline Width $^{\mathrm{d}}(\mathrm{m})$ & & $2.2 \pm 0.6$ & $7.1 \pm 2.1$ & $34.0 \pm 4.8$ & $46.5 \pm 6.5$ \\
\hline Velocity $^{\mathrm{d}}\left(\mathrm{m} \mathrm{s}^{-1}\right)$ & & $0.05 \pm 0.02$ & $0.12 \pm 0.04$ & $0.37 \pm 0.05$ & $0.46 \pm 0.06$ \\
\hline Water surface area ${ }^{\mathrm{e}}\left(\mathrm{km}^{2}\right)$ & & $3.5 \pm 1.0$ & $5.3 \pm 1.6$ & $3.9 \pm 0.5$ & $1.9 \pm 0.3$ \\
\hline $\operatorname{Slope}^{f}(\%)$ & & $0.310 \pm 0.28$ & $0.23 \pm 0.14$ & 0.11 & 0.04 \\
\hline $\mathrm{k}_{\mathrm{b}}^{\mathrm{g}} \mathrm{l}\left(\mathrm{m} \mathrm{d}^{-1}\right)$ & & $1.2 \pm 0.6$ & $1.9 \pm 0.4$ & $3.4 \pm 0.8$ & $2.1 \pm 0.5$ \\
\hline Number of the studied stations & 3 & 6 & 6 & 4 & 2 \\
\hline River width of the studied stations ${ }^{\mathrm{h}}(\mathrm{m})$ & & $1.7 \pm 1.2$ & $5.2 \pm 2.4$ & $15 \pm 5.5$ & $31 \pm 10.8$ \\
\hline River length of the studied stations ${ }^{\mathrm{i}}(\mathrm{km})$ & & $2.6 \pm 1.4$ & $10.8 \pm 4.6$ & $57.5 \pm 7.5$ & 40 \\
\hline Forest occupation of the studied stations ${ }^{\mathrm{j}}(\%)$ & 100 & $96 \pm 3$ & $86 \pm 3$ & $83 \pm 2$ & $84 \pm 0.4$ \\
\hline Catchment surface area of the studied stations ${ }^{\mathrm{k}}\left(\mathrm{km}^{2}\right)$ & & $15 \pm 13$ & $98 \pm 40$ & $446 \pm 99$ & $1,863 \pm 240$ \\
\hline Number of gauging stations ${ }^{1}$ & & 0 & 2 & 1 & 1 \\
\hline Depth of the gauging stations ${ }^{\mathrm{m}}(\mathrm{m})$ & & $0.13 \pm 0.01$ & $0.32 \pm 0.16$ & $0.72 \pm 0.32$ & $1.14 \pm 0.85$ \\
\hline Water velocity $^{\mathrm{n}}\left(\mathrm{m} \mathrm{s}^{-1}\right)$ & & $0.10 \pm 0.08$ & & & \\
\hline
\end{tabular}

* Order zero corresponds to groundwater.

$\mathrm{a}, \mathrm{i}$ Calculated from the BD CARTHAGE ${ }^{\circledR}$ (www.ign.fr).

${ }^{\mathrm{b}}$ Estimated from our hydrological model and from the mean river flow of $21.3 \mathrm{~m}^{3} \mathrm{~s}^{-1}$ at the most downstream gauging station during the sampling period (Table 2).

${ }^{\mathrm{c}}$ Mean river flow $\left(\mathrm{Q}_{\text {mean }}\right)$ is determined with the cumulated river flow and the number of streams per stream order.

${ }^{\mathrm{d}}$ Estimated using hydraulic equations from Raymond et al. (2012).

e Estimated from cumulated river length and mean width per stream orders from Raymond et al. (2012).

f, $\mathrm{k}$ Estimated from ArcGIS 10.2 (spatial analyst extension).

g Estimated as the average ( \pm SD) gas transfer velocity given by the 7 empirical equations from Raymond et al. (2012).

${ }^{\mathrm{h}}$ Estimated from field measurements (decametre or laser rangefinder).

${ }^{\mathrm{j}}$ Estimated with CORINE land cover 2006 (EEA, 2014).

${ }^{1}$ Gauging stations are included in the number of the studied stations.

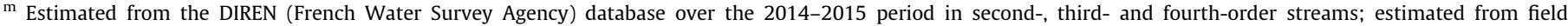
measurements in first-order streams (in the headwater spring and in a larger first-order stream).

${ }^{n}$ Estimated from field measurements (in the headwater spring and in a larger first-order stream).

Raymond et al. (2012). We estimated width $(W)$, depth $(D)$ and velocity $(V)$ for each stream order as follows (Table 1 ):

$W=a Q_{\text {mean }}^{b} ; D=c Q_{\text {mean }}^{d} ; V=e Q_{\text {mean }}^{f}$

where $a, c$, and $e$ are geometry coefficients equal to $12.88,0.4$, and 0.29 , respectively, and $b, d$, and $f$ are geometry exponents equal to $0.42,0.29$, and 0.29 , respectively (Raymond et al. 2012). $Q_{\text {mean }}$ is the mean river flow per stream order (Table 1).We used the mean width (estimated from Raymond et al., 2012) and the cumulated river length per stream order (estimated from BD CARTHAGE ${ }^{\circledR}$ ) to calculate the stream surface area per stream order (Table 1). We also used the parameters $W, D, V$ and $S$ to determine the gas transfer velocity in each stream order, using the 7 empirical equations determined in Raymond et al. (2012) (Table 1).

\subsubsection{Field work}

During the sampling period (Jan. 2014-Jul. 2015), the 21 stations (18 surface water stations and 3 groundwater stations) were sampled at monthly time intervals. In addition, we sampled the groundwater resurgence five times and sampled a small headwater $40 \mathrm{~m}$ immediately downstream from the resurgence. The headwater has a mean depth of $5 \mathrm{~cm}$ and a mean width of $20 \mathrm{~cm}$. We estimated the discharge of the small headwater during two different periods (Feb. 2015 and Jul. 2015). We used a calibrated bucket and timed how long it took to fill. We repeated this operation 10 times for the two different periods.

In total, we collected 292 samples for concomitant measurements of temperature, $\mathrm{pH}, \mathrm{pCO}_{2}$, TA, calculated DIC and $\delta^{13} \mathrm{C}$-DIC.

In the field, the partial pressure of $\mathrm{CO}_{2}\left(\mathrm{pCO}_{2}\right)$ in the groundwater, stream water and river water was measured directly using an equilibrator (Frankignoulle and Borges, 2001; Polsenaere et al., 2013). This equilibrator was connected to an infrared Gas analyser
(LI-COR $\left.{ }^{\circledR}, \mathrm{LI}-820\right)$, which was calibrated one day before sampling on two linear segments because of its non-linear response in the range of observed $\mathrm{pCO}_{2}$ values $(0-90,000 \mathrm{ppmv})$. This nonlinearity was due to saturation of the infrared cell at $\mathrm{pCO}_{2}$ values above 20,000 ppmv. We used certified standards (Air Liquide ${ }^{\mathrm{TM}}$ France) of 2,079 $\pm 42,19,500 \pm 390$ and 90,200 $\pm 1,800 \mathrm{ppmv}$, as well as nitrogen flowing through soda lime for zero. For the first linear segment [0-20,000 ppmv], which corresponded to the river waters, we set the zero, spanned the LI-COR at 19,500 ppmv, and then checked for linearity at 2,042 ppmv. For the second segment $[20,000-90,000 \mathrm{ppmv}]$, which corresponded to the sampled groundwater, we measured the response of the LI-COR with the standard at 90,000 ppmv and used this measured value to make a post-correction of the measured value in the field. For the groundwater, we took the precaution to renew the water in the piezometers by pumping with a submersible pump before sampling. The groundwater was then sampled when the stabilization of the groundwater temperature, $\mathrm{pH}$, electrical conductivity and dissolved oxygen saturation monitored with portable probes was observed.

The $\delta^{13} \mathrm{C}$-DIC and DIC samples were collected using $120 \mathrm{~mL}$ glass serum bottles sealed with a rubber stopper and treated with $0.3 \mathrm{~mL}$ of $\mathrm{HgCl}_{2}$ at $20 \mathrm{~g} \mathrm{~L}^{-1}$ to avoid any microbial respiration during storage. Vials were carefully sealed, taking care that no air remained in contact with samples. Vials are also stored in the dark to prevent photooxidation.

We stored the sampled TA in polypropylene bottles after filtration using a syringe equipped with a glass fibre $(0.7 \mu \mathrm{m})$.

We also measured the $\mathrm{pH}( \pm 0.05)$, temperature $\left( \pm 0.05^{\circ} \mathrm{C}\right)$ and conductivity $( \pm 0.5 \%)$ in situ with a specific probe (Metrohm). Before the start of each sampling trip, the $\mathrm{pH}$ probe was calibrated using the NBS buffer solutions (4, 7 and 10). 
Table 2

Hydrological model of the Leyre watershed.

\begin{tabular}{|c|c|c|c|c|c|c|}
\hline \multirow{2}{*}{$\begin{array}{l}\text { Stream order } \\
\text { Gauging stations }\end{array}$} & & \multirow[t]{2}{*}{ Order 1} & \multicolumn{2}{|c|}{ Order 2} & \multirow{2}{*}{$\begin{array}{c}\text { Order } 3 \\
\text { PL }\end{array}$} & \multirow{2}{*}{$\begin{array}{c}\text { Order } 4 \\
\text { GL }\end{array}$} \\
\hline & & & GAR & BR & & \\
\hline \multirow[t]{3}{*}{ 2014-2015 } & $\mathrm{Q}\left(\mathrm{m}^{3} \mathrm{~s}^{-1}\right)$ & & $1.0 \pm 1.3$ & $0.4 \pm 0.5$ & \multirow{2}{*}{$\begin{array}{c}3.5 \pm 3.7 \\
855 \pm 920\end{array}$} & $17.9 \pm 20.4$ \\
\hline & $\operatorname{Dr}\left(\mathrm{m}^{3} \mathrm{~km}^{-2} \mathrm{~s}^{-1}\right)$ & & $765 \pm 970$ & $920 \pm 1340$ & & $940 \pm 1,070$ \\
\hline & DE (unitless) & & & & $0.98 \pm 0.28^{* *}$ & $1.05 \pm 0.15$ \\
\hline \multirow[t]{6}{*}{$01 / 04 / 2015$} & $\mathrm{Q}_{1}$ & 0.305 & 1.29 & 0.435 & & \\
\hline & $\mathrm{Dr}_{1}$ & 773 & 995 & 1,140 & & \\
\hline & $\mathrm{DE}_{1}$ & & 1.29 & 1.48 & & \\
\hline & $\mathrm{Q}_{2}$ & 0.276 & 1.29 & 0.435 & & \\
\hline & $\mathrm{Dr}_{2}$ & 732 & 995 & 1,140 & & \\
\hline & $\mathrm{DE}_{2}$ & & 1.36 & 1.56 & & \\
\hline \multirow[t]{6}{*}{$22 / 02 / 2016$} & $\mathrm{Q}_{3}$ & 0.304 & 2.30 & 0.487 & & \\
\hline & $\mathrm{Dr}_{3}$ & 771 & 1,774 & 1,275 & & \\
\hline & $\mathrm{DE}$ & & 2.30 & 1.65 & & \\
\hline & $\mathrm{Q}_{4}$ & 0.233 & 2.30 & 0.487 & & \\
\hline & $\mathrm{Dr}_{4}$ & 610 & 1,774 & 1,275 & & \\
\hline & $\mathrm{DE}_{4}$ & & 2.91 & 2.09 & & \\
\hline \multirow[t]{2}{*}{ Hydrological model } & $\mathrm{DE}_{\text {mean }}$ & & \multicolumn{2}{|c|}{$1.83 \pm 0.53$} & $1.20 \pm 0.36$ & $1.05 \pm 0.15$ \\
\hline & $\%$ of groundwater & $100 \%$ & \multicolumn{2}{|c|}{$45 \%$} & $17 \%$ & $5 \%$ \\
\hline
\end{tabular}

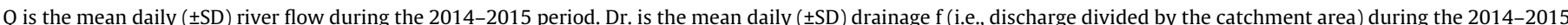

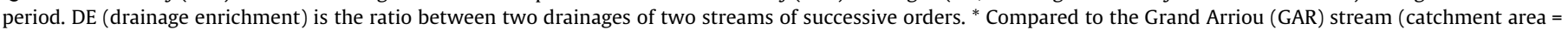

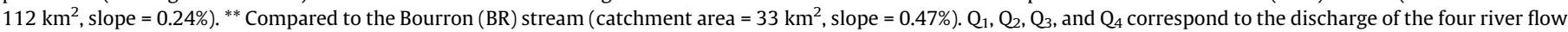

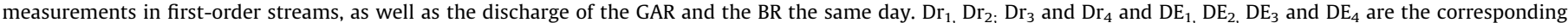

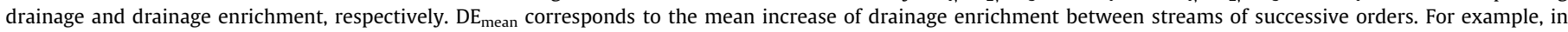

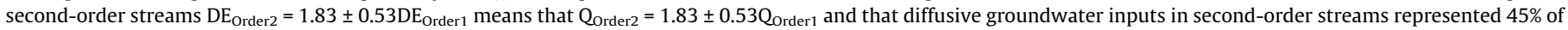
their water discharge, while the $55 \%$ remaining is coming from first-order streams.

\subsection{Laboratory analysis}

The $\delta^{13} \mathrm{C}$-DIC was measured following the procedure of Gillikin and Bouillon (2007). A headspace was first created in the $120 \mathrm{~mL}$ serum vial by injecting $25 \mathrm{~mL}$ of helium gas. Then, $0.3 \mathrm{~mL}$ of warm $85 \%$ phosphoric acid was added in order to titrate all bicarbonates and carbonates to $\mathrm{CO}_{2}$. To ensure gas equilibration, the vials were strongly shaken. Measurements were performed using a isotope ratio mass spectrometer (Micromass IsoPrime), equipped with a manual gas injection port. We twice injected $2 \mathrm{~mL}$ of headspace gas from the vial headspace. The carbon isotope ratio is expressed in delta notation $\left(\delta^{13} \mathrm{C}\right)$ relative to Pee Dee Belemnite. $\delta^{13} \mathrm{C}$-DIC was calibrated against a laboratory standard $\left(45 \mathrm{mg}\right.$ of $\mathrm{Na}_{2} \mathrm{CO}_{3}$ were introduced in a sealed vial flushed with helium and were then dissolved with $3 \mathrm{~mL}$ of warm $85 \%$ phosphoric acid); this standard had been calibrated against a certified standard (NBS19, -1.96\%) using a dual-inlet IRMS (Micromass IsoPrime). The isotopic value of the $\mathrm{Na}_{2} \mathrm{CO}_{3}$ standard was $-4.5 \pm 0.2 \%$. Finally, to correct for the partitioning of $\mathrm{CO}_{2}$ between the headspace and water phase in the samples and to calculate the $\delta^{13} \mathrm{C}$ of the total DIC, the isotopic fractionation of $\mathrm{CO}_{2}$ at the water-air interface as a function of lab temperature of Miyajima et al. (1995) was applied.

TA was analysed on filtered samples by automated electrotitration on $50 \mathrm{~mL}$ filtered samples with $0.1 \mathrm{~N} \mathrm{HCl}$ as the titrant. The equivalence point was determined from $\mathrm{pH}$ between 4 and 3 with the Gran method (Gran, 1952). The precision based on replicate analyses was better than $\pm 5 \mu \mathrm{M}$. For samples with a very low $\mathrm{pH}$ $(<4.5)$, we bubbled the water with atmospheric air in order to degas the $\mathrm{CO}_{2}$. Consequently, the initial $\mathrm{pH}$ increased above the value of 5 , and the TA titration could then be performed (Abril et al., 2015).

We calculated DIC from $\mathrm{pCO}_{2}$, TA, and temperature measurements using the carbonic acid dissociation constants of Millero (1979) and the $\mathrm{CO}_{2}$ solubility from Weiss (1974), as implemented in the $\mathrm{CO}_{2} \mathrm{SYS}$ programme (Lewis et al., 1998). We also performed some direct measurements of DIC on a selection of 239 samples. DIC was measured in an extra sealed $120 \mathrm{~mL}$ serum vial, after creating a headspace of $25 \mathrm{~mL}$ with nitrogen gas, acidifying with 0.3
$\mathrm{mL}$ of $85 \%$ phosphoric acid, and shaking. The gas mixture from the headspace was analysed by injecting $0.5 \mathrm{~mL}$ of gas through a septum in a closed loop connected to the LI-COR LI-820 (air flow $0.5 \mathrm{~L}$ $\mathrm{min}^{-1}$ ). Soda lime was placed after the gas analyser and ensures a zero baseline at the entrance of the infrared gas analyser. Peak areas were recorded, integrated and compared to those obtained with standards made by dissolving well-known amounts of $\mathrm{CaCO}_{3}$ in distilled water at the atmospheric $\mathrm{pCO}_{2}$. The $\mathrm{pH}$ and TA were also measured to check the calculated DIC concentration in these standards. The DIC concentrations in the samples were calculated from the water and headspace volumes and the solubility coefficient of $\mathrm{CO}_{2}$ (Weiss, 1974). The directly measured DIC was consistent with the DIC calculated from $\mathrm{pCO}_{2}$ and TA at $\pm 15 \%$ for a DIC range of $90-5,370 \mu \mathrm{mol} \mathrm{L}^{-1}$. Therefore, we report here the DIC dataset based on the calculation with $\mathrm{pCO}_{2}$ and TA.

\subsection{Degassing experiment}

We performed experimental degassing of dissolved $\mathrm{CO}_{2}$ to (i) prove that degassing alone strongly alters the $\delta^{13} \mathrm{C}$-DIC signature and (ii) prove that the isotopic equilibration accompanying $\mathrm{CO}_{2}$ degassing follows the theory described by the degassing model (Supplementary material).

We collected two $10 \mathrm{~L}$ containers of groundwater in the field and filled the containers to the top without air to limit degassing. The water was treated immediately in the field with $\mathrm{HgCl}_{2}$ to inhibit respiration. Back in the laboratory, we pumped this water to the equilibrator to continuously monitor the $\mathrm{pCO}_{2}$. The outlet of the equilibrator was connected to the container and recirculating the water in a closed circuit. When the value of $\mathrm{pCO}_{2}$ was stable, we collected a sample in a $120 \mathrm{~mL}$ vial to perform $\delta^{13} \mathrm{C}$-DIC measurements thereafter. Then, we aerated the water by bubbling air from the outside (thus containing $\mathrm{CO}_{2}$ with approximately the atmospheric concentration and isotopic value, i.e., $400 \mathrm{ppmv}$ and $-8 \%$ ) using an air pump and a bubbling system. The fact that $\mathrm{CO}_{2}$ was artificially degassed (by bubbling atmospheric air with the same $\mathrm{CO}_{2}$ concentration and $\delta^{13} \mathrm{C}$ signature as in the field) is not a problem because the objective is not to describe the real 
intensity of $\mathrm{CO}_{2}$ degassing as it occurs in streams but rather to describe the relations between $\mathrm{pCO}_{2}$, DIC and $\delta^{13} \mathrm{C}$-DIC when $\mathrm{CO}_{2}$ degasses. When the decrease in $\mathrm{pCO}_{2}$ was sufficient (for increments between 8,000 and 100 ppmv depending on the concentration), we stopped the aeration, waited for a stable $\mathrm{pCO}_{2}$ signal, and sampled again for $\delta^{13} \mathrm{C}$-DIC measurements. We repeated this operation until the water $\mathrm{pCO}_{2}$ was equilibrated with the atmosphere. We also measured the TA, before and after each experiment. The experiment was reproduced on two occasions, and we obtained a total of 35 pairs of $\mathrm{pCO}_{2}$ and $\delta^{13} \mathrm{C}$-DIC values or pairs of calculated DIC and $\delta^{13} C$-DIC values, after verifying that the TA was not affected by the degassing and constant during the experiment.

\section{Results}

\subsection{Hydrology and water mass balance in the Leyre watershed}

During the monitoring period (Jan. 2014-Jul. 2015), the hydrology was characterized by an average discharge of $21.3 \mathrm{~m}^{3} \mathrm{~s}^{-1}$ at the most downstream gauging station (Fig. 1; Fig. 2a), including two relatively short flood events (further referred to as "high flow period") in Jan. 2014-Mar. 2014 (peak of $120 \mathrm{~m}^{3} \mathrm{~s}^{-1}$ ) and in Feb. 2015-Mar. 2015 (peak of $60 \mathrm{~m}^{3} \mathrm{~s}^{-1}$ ) and two longer periods of low flow (further referred to as "base flow period") between Apr. 2014-Jan. 2015 and Apr. 2015-Jul. 2015 (minimum flow of 5.1 $\mathrm{m}^{3} \mathrm{~s}^{-1}$ in Nov. 2014). Periods of groundwater discharging (decreasing water table) were Jan. 2014-Oct. 2014 and Mar. 2015-Jul. 2015 , and a period of groundwater loading (increasing water table) was Nov. 2014-Mar. 2015 (Fig. 2a).

The spatial increase in the drainage enrichment (i.e., parameter DE) between streams of successive orders provides an estimate of the additional water flows from diffusive groundwater inputs in stream orders $1-4$, compared to that coming from the streams immediately upstream (because surface runoff does not occur in the Leyre watershed) (Table 2). This assumption is further checked when we closed the mass balance of DIC with the calculated water budget (see part 4.3). We found the following drainage enrichment between discharges in streams of successive order (Table 2):

$Q_{\text {Or2 }}=1.83 \pm 0.53 Q_{\text {or1 }}$

$Q_{\text {or3 }}=1.20 \pm 0.36 Q_{\text {Or2 }}$

$Q_{\text {Or } 4}=1.05 \pm 0.15 Q_{\text {or } 3}$

These downstream increases in drainage reflect the contributions of groundwater inputs in each stream order, relative to runoff from upstream. Thus, the water balance in the Leyre watershed during the two year period (Jan. 2014-Dec. 2015) can be described as follows:

$Q_{\text {or1 }}=G W_{1}(100 \%)$

$Q_{\text {or2 }}=G W_{2}(45 \%)+Q_{o r 1}(55 \%)$

$Q_{O r 3}=G W_{3}(17 \%)+Q_{O r 2}(83 \%)$

$Q_{O r 4}=G W_{4}(5 \%)+Q_{o r 3}(95 \%)$

thus,

$Q_{\text {Or4 }}=Q_{\text {Or2 }}(55 \%)+G W_{3}(16 \%)+G W_{4}(5 \%)$

$Q_{\text {Or } 4}=Q_{\text {Or1 }}(43 \%)+G W_{2}(36 \%)+G W_{3}(16 \%)+G W_{4}(5 \%)$

where $Q_{O r 1}, Q_{O r 2}, Q_{O r 3}$ and $Q_{O r 4}$ refer to the river discharge of each stream order; $G W_{1}, G W_{2}, G W_{3}$ and $G W_{4}$ refer to the groundwater inputs in each stream order; and the percentage in parentheses refers to the relative contribution of each term to the total. Note
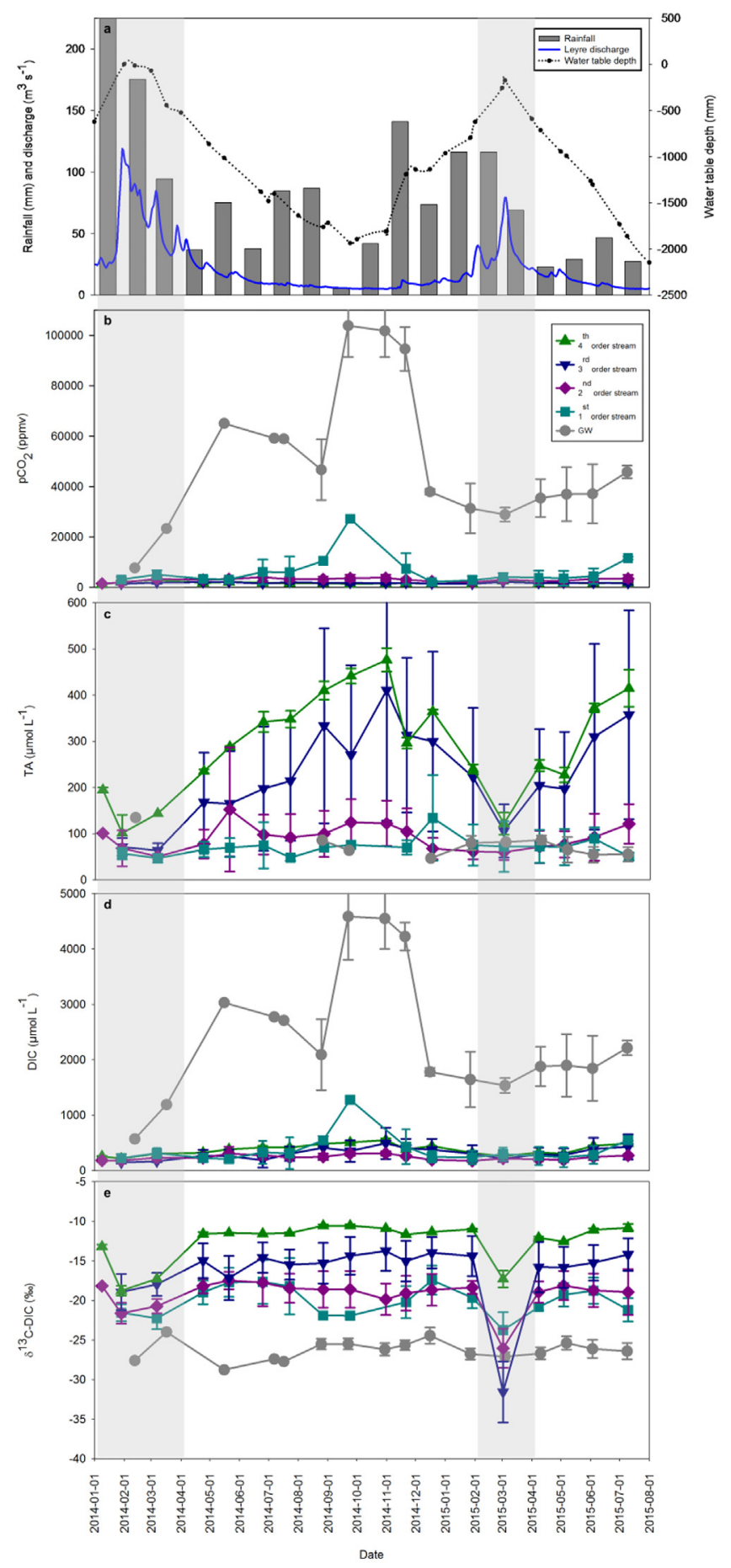

Fig. 2. Seasonal variations of hydrology and inorganic carbon speciation and isotopic composition in the different stream orders of the Leyre catchment. (a) Daily discharge of the Leyre River at the most downstream gauging station, water table depth at the Bilos station and monthly precipitation at the Belin-Beliet municipality (30 km from Bilos), (b) partial pressure of carbon dioxide $\left(\mathrm{pCO}_{2}\right),(\mathrm{c})$ total alkalinity (TA), (d) dissolved inorganic carbon (DIC), (e) stable isotope composition of DIC $\left(\delta^{13} \mathrm{C}\right.$-DIC). Each point represents the mean value obtained at different stations with the same stream order (spatial average), and the error bars correspond to the Pearson standard deviation (spatial heterogeneity). Grey side bar represents high flow periods.

that $Q_{\text {or } 1}$ is equivalent to $G W_{1}$, because in first-order streams all the water originates from groundwater.

River widths $(W)$, depths $(D)$ and velocities $(V)$ modelled with hydraulic equations of Raymond et al. (2012) for each stream order 
in the Leyre watershed are shown in Table 1, together with the available measurements of these three parameters. The modelled values of depths compared very well ( $<15 \%$ difference) with those observed daily at the gauging stations in streams with orders 2,3 and 4 . In the Leyre basin, the river network for stream orders 1 and 2 is highly human-managed. Hence, the modelled width values compared well with those measured in the field (Table 1). In contrast, in the Leyre basin, third- and fourth-order streams are natural and thus the spatial variability of width is higher than in streams of orders 1 and 2 . Hence, the modelled width values in streams are further away from those measured in the field (Table 1). The modelled river velocities increased from less than $10 \mathrm{~cm}$ per second in first-order streams to a maximum of $50 \mathrm{~cm}$ per second in fourth-order streams. The velocities values in firstorder streams were consistent with those measured in the headwaters and a relatively large first-order stream (Table 1 ).

\subsection{Spatiotemporal variations of $\mathrm{pCO}_{2}$, TA, DIC and $\delta^{13} \mathrm{C}-\mathrm{DIC}$}

Throughout the sampling period, $\mathrm{pCO}_{2}$, TA, DIC and stable isotope ratios of DIC varied greatly in time (Fig. 2) and space (Table 3; Fig. 3) along an upstream-downstream gradient (from groundwater to fourth-order streams). A significant decrease in $\mathrm{pCO}_{2}$ was observed while the river order was increasing (Table 3; Fig. 3a). On a yearly average, the $\mathrm{pCO}_{2}$ values were $48,070 \pm 26,320$, $4,820 \pm 4,540,3,000 \pm 1,090,1,740 \pm 580$ and $1,740 \pm 460 \mathrm{ppmv}$ for groundwater and first-, second-, third- and fourth-order streams, respectively (Table 3; Fig. 3a). Temporally, the stronger variations in $\mathrm{pCO}_{2}$ occurred in groundwater and first-order streams (Fig. 2b). In groundwater, an increase in $\mathrm{pCO}_{2}$ (from 7,700 to $103,870 \pm 12,510 \mathrm{ppmv}$ ) occurred during discharging periods (Fig. 2a and b). In contrast, a rapid decrease in $\mathrm{pCO}_{2}$ (down to $28,890 \pm 2,790$ ppmv in Mar. 2015) was observed during loading periods, when groundwater was apparently diluted with rainwater (Fig. 2a and b). This loading period during the winter also corresponded to a decrease in soil temperature. The same temporal trend occurred in first-order streams, although with an amplitude much smaller $(3,700 \pm 1,530-27,205 \mathrm{ppmv})$ than that in groundwater (7,680-103,870 $\pm 12,510 \mathrm{ppmv})$, attesting the strong hydrological connectivity between groundwater and first-order streams (Fig. 2b).

During the entire sampling period, the TA values were not significantly different $(\mathrm{p}>0.05)$ in groundwater and first- and second-order streams (Table 3; Fig. 3b). Indeed, on an annual average, the TA was $71 \pm 25,74 \pm 45$ and $90 \pm 60 \mu \mathrm{mol} \mathrm{L}^{-1}$, respectively for groundwater and first- and second-order streams (Table 3; Fig. 3). In contrast, a significant increase $(p<.001)$ in TA was observed between second-, third- and fourth-order streams ( $\mathrm{p}<$ .05 ), where mean values of TA were $230 \pm 190$ and $300 \pm 110$ $\mu \mathrm{mol} \mathrm{L}{ }^{-1}$, respectively, for third- and fourth-order streams (Table 3; Fig. 3b). On the one hand, throughout the sampling period, the results did not show important temporal variations of TA in groundwater and first- and second-order streams (Table 3; Fig. 2c). On the other hand, seasonal variations were observed in third- (range $65 \pm 15-410 \pm 280 \mu \mathrm{mol} \mathrm{L}^{-1}$ ) and fourth-order (range $100 \pm 40-480 \pm 25 \mu \mathrm{mol} \mathrm{L}^{-1}$ ) streams (Fig. 2c). The TA in third- and fourth-order streams increased during the groundwater discharging period and decreased during the groundwater loading period, to reach a minimum value during flood peak (Fig. 2a and c).

DIC concentrations and isotopic composition showed a clear spatial trend along the groundwater-stream-river continuum (Fig. $3 \mathrm{c}$ and d). The DIC concentrations significantly decreased ( $\mathrm{p}$ $<.001$ ) from $2300 \pm 1120 \mu \mathrm{mol} \mathrm{L}^{-1}$ in groundwater to $310 \pm 210$ $\mu \mathrm{mol} \mathrm{L}{ }^{-1}$ in first-order streams (Table 3; Fig. 3c), as observed with $\mathrm{pCO}_{2}$. Paralleling this, the $\delta^{13} \mathrm{C}$-DIC increased from $-26.2 \pm 1.2 \%$ in groundwater to $-19.8 \pm 2.7 \%$ in first-order streams (Table 3 ; Fig. 3d). Further downstream, the DIC concentrations remained globally constant $(\mathrm{p}>.05)$ in first- (mean is $\left.310 \pm 210 \mu \mathrm{mol} \mathrm{L}^{-1}\right)$, second- $\left(240 \pm 65 \mu \mathrm{mol} \mathrm{L}^{-1}\right)$ and third-order $\left(310 \pm 180 \mu \mathrm{mol} \mathrm{L}^{-1}\right)$ streams and were significantly increased $(p<.05)$ in fourth-order streams $\left(380 \pm 100 \mu \mathrm{mol} \mathrm{L}^{-1}\right)$ (Table 3; Fig. 3c). The latter increase was related to an increase in TA (Fig. 3b) and was also concomitant with a significant $(\mathrm{p}<0.01)$ increase in $\delta^{13} \mathrm{C}$-DIC from $-16.2 \pm$ $4.4 \%$ in third-order streams to $-14.1 \pm 2.4 \%$ in fourth-order streams (Table 3; Fig. 3d). The stable isotope compositions of DIC were globally constant in groundwater $(-26.2 \pm 1.2 \%$ ) (Table 3 ; Fig. 2).

\subsection{Spring waters}

We sampled one groundwater resurgence immediately where the groundwater was entering the headwater, as well in the headwater $40 \mathrm{~m}$ downstream of the resurgence. This sampling was completed in order to see how fast $\mathrm{CO}_{2}$ degassing could occur in very small streams and how the $\delta^{13} \mathrm{C}$-DIC signal could be affected when the $\mathrm{CO}_{2}$ that originates from groundwater is degassed to the atmosphere. All discharge in the stream was apparently coming from the sampled spring. For the five sampling periods, values of $\mathrm{pCO}_{2}$ in the resurgence were $22,370,30,000,32,170,34,950$ and 37,500 ppmv, whereas those in the headwater ( $40 \mathrm{~m}$ downstream) were $6,560,9,950,10,100,11,050$ and 10,900 ppmv. On average, spring waters had lost $70 \%$ of their dissolved $\mathrm{CO}_{2}$ over $40 \mathrm{~m}$. The values of $\delta^{13}$ C-DIC were $-26.7,-26.7,-24.7,-24.6$ and $-25.6 \%$ in the spring, whereas they were $-20.4,-21.5,-21.9,-21.6$ and $-19.5 \%$ in the headwater. Consequently, for the five sampling periods, the $\mathrm{pCO}_{2}$ decreased by $21,700 \pm 6,800$ ppmv over $40 \mathrm{~m}$, while the $\delta^{13} \mathrm{C}$-DIC increased by $+4.7 \pm 1.7 \%$. In addition, for a mean water velocity of $5 \mathrm{~cm} \mathrm{~s}^{-1}$, the travel time between the

Table 3

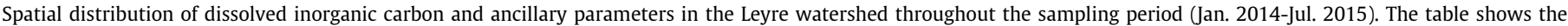

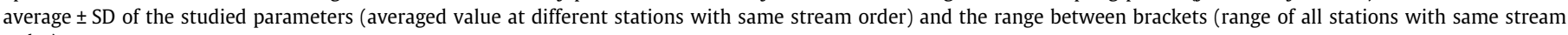
order).

\begin{tabular}{|c|c|c|c|c|c|c|c|}
\hline & $\mathrm{T}\left({ }^{\circ} \mathrm{C}\right)$ & $\mathrm{pH}$ & Conductivity $\left(\mu \mathrm{S} \mathrm{cm}^{-1}\right)$ & $p \mathrm{CO}_{2}(\mathrm{ppmv})$ & $\mathrm{TA}\left(\mu \mathrm{mol} \mathrm{L}^{-1}\right)$ & $\mathrm{DIC}\left(\mu \mathrm{mol} \mathrm{L}^{-1}\right)$ & $\delta^{13} \mathrm{C}$-DIC $(\% o)$ \\
\hline Groundwater & $\begin{array}{l}13.5 \pm 2.2 \\
{[8.5-17.9]}\end{array}$ & $\begin{array}{l}4.5 \pm 0.2 \\
{[3.7-4.8]}\end{array}$ & $\begin{array}{l}113 \pm 45 \\
{[67-268]}\end{array}$ & $\begin{array}{l}49,410 \pm 26,320 \\
{[7,680-116,380]}\end{array}$ & $\begin{array}{l}71 \pm 25 \\
{[32-135]}\end{array}$ & $\begin{array}{l}2,360 \pm 1,160 \\
{[570-5,370]}\end{array}$ & $\begin{array}{l}-26.2 \pm 1.2 \\
{[-28.8 \text { to }-23.4]}\end{array}$ \\
\hline First-order & $\begin{array}{l}12.9 \pm 4 \\
{[4.8-22.1]}\end{array}$ & $\begin{array}{l}5.9 \pm 0.4 \\
{[5.1-6.9]}\end{array}$ & $\begin{array}{l}116 \pm 28 \\
{[72-187]}\end{array}$ & $\begin{array}{l}4,820 \pm 4,540 \\
{[1,010-27,205]}\end{array}$ & $\begin{array}{l}74 \pm 45 \\
{[29-280]}\end{array}$ & $\begin{array}{l}310 \pm 210 \\
{[87-1,280]}\end{array}$ & $\begin{array}{l}-19.8 \pm 2.7 \\
{[-27.6 \text { to }-12.4]}\end{array}$ \\
\hline Second-order & $\begin{array}{l}12.8 \pm 2.7 \\
{[6.3-18.3]}\end{array}$ & $\begin{array}{l}6.1 \pm 0.5 \\
{[4.6-6.9]}\end{array}$ & $\begin{array}{l}120 \pm 35 \\
{[62-256]}\end{array}$ & $\begin{array}{l}3,000 \pm 1,090 \\
{[1,445-6,430]}\end{array}$ & $\begin{array}{l}90 \pm 60 \\
{[30-410]}\end{array}$ & $\begin{array}{l}240 \pm 65 \\
{[140-545]}\end{array}$ & $\begin{array}{l}-19.3 \pm 2.7 \\
{[-27.4 \text { to }-13.5]}\end{array}$ \\
\hline Third-order & $\begin{array}{l}13.4 \pm 3.1 \\
{[7.8-19.5]}\end{array}$ & $\begin{array}{l}6.6 \pm 0.5 \\
{[5.5-7.5]}\end{array}$ & $\begin{array}{l}130 \pm 20 \\
{[83-180]}\end{array}$ & $\begin{array}{l}1,740 \pm 580 \\
{[1,058-3,271]}\end{array}$ & $\begin{array}{l}230 \pm 190 \\
{[35-715]}\end{array}$ & $\begin{array}{l}310 \pm 180 \\
{[120-780]}\end{array}$ & $\begin{array}{l}-16.2 \pm 4.4 \\
{[-35.4 \text { to }-11.5]}\end{array}$ \\
\hline Fourth-order & $\begin{array}{l}13.6 \pm 3 \\
{[9-18.4]}\end{array}$ & $\begin{array}{l}6.8 \pm 0.3 \\
{[5.9-7.3]}\end{array}$ & $\begin{array}{l}150 \pm 20 \\
{[81-198]}\end{array}$ & $\begin{array}{l}1,740 \pm 460 \\
{[1,163-2,925]}\end{array}$ & $\begin{array}{l}300 \pm 110 \\
{[60-500]}\end{array}$ & $\begin{array}{l}380 \pm 100 \\
{[140-580]}\end{array}$ & $\begin{array}{l}-14.1 \pm 2.4 \\
{[-21.1 \text { to }-11.9]}\end{array}$ \\
\hline
\end{tabular}



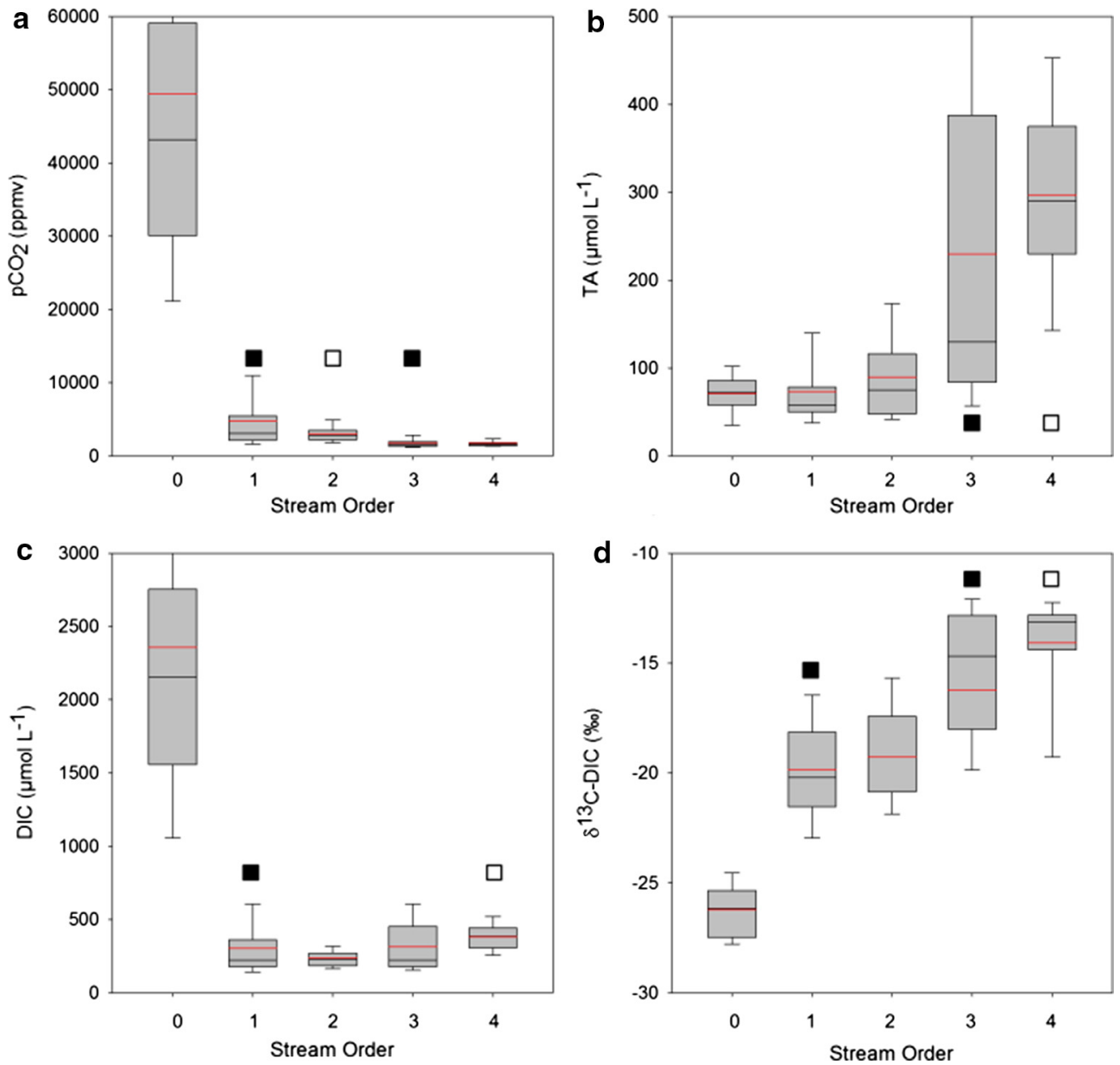

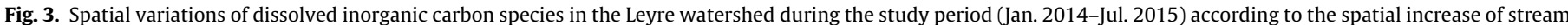

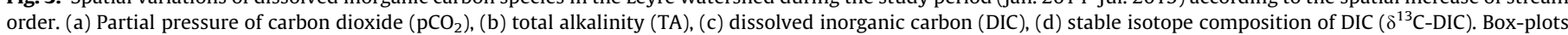

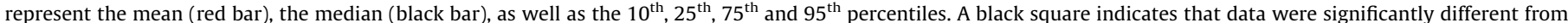

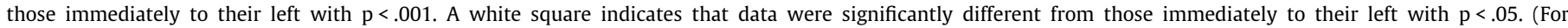
interpretation of the references to colour in this figure legend, the reader is referred to the web version of this article.)

spring and the sampling point in the headwater was covered in approximately $10 \mathrm{~min}$.

\subsection{Degassing experiment}

We tried to reproduce in the degassing experiment the results observed previously for spring waters (Fig. 4). We assumed that, if the experimental points of $\mathrm{pCO}_{2}$ versus $\delta^{13} \mathrm{C}$-DIC correlate well with the degassing model (Supplementary material), this enables us to valid the model on a small spatial scale (headwater scale). In small headwaters, the metabolism is believed to be a minor component of the degassing (Hotchkiss et al., 2015). The initial $\mathrm{pCO}_{2}$ values were 41,160 and $47,730 \mathrm{ppmv}$, the TA concentrations were 35 and $70 \mu \mathrm{mol} \mathrm{L}^{-1}$, the DIC concentrations were 1,720 and $2,030 \mu \mathrm{mol} \mathrm{L}^{-1}$, and the $\delta^{13} \mathrm{C}$-DIC values were $-26.2 \pm 0.1 \%$ and $-26.5 \pm 0.04 \%$ o for the two experiments, respectively (Fig. 4). The final $\mathrm{pCO}_{2}$ values were 530 and 460 ppmv, the TA concentrations were 35 and $70 \mu \mathrm{mol} \mathrm{L} \mathrm{L}^{-1}$, the DIC concentrations were 55 and $90 \mu \mathrm{mol} \mathrm{L} \mathrm{L}^{-1}$, and the $\delta^{13} \mathrm{C}$-DIC values were $-18.4 \pm 0.4 \%$ and $-14.2 \pm 1.2 \%$ for the two experiments, respectively (Fig. 4).

First, a rapid decrease in the $\mathrm{pCO}_{2}$ occurred (from 41,160 to 9,360 ppmv and from 47,730 to 3,260 ppmv, for the two experiments, respectively) and in DIC (from 1,720 to $420 \mu \mathrm{mol} \mathrm{L}^{-1}$ and from 2,030 to $200 \mu \mathrm{mol} \mathrm{L}^{-1}$ ) (Fig. 4). This first period of large and rapid $\mathrm{CO}_{2}$ degassing was associated with a moderate increase in $\delta^{13} \mathrm{C}$-DIC (from $-26.2 \pm 0.5$ to $-24.3 \pm 0.03 \%$ and from $-26.5 \pm$
0.04 to $-22.5 \pm 0.2 \%$ ) (Fig. 4). Later, slower decreases in $\mathrm{pCO}_{2}$ (from 9,360 to 530 ppmv and from 3,260 to 460 ppmv) and in DIC (from 420 to $55 \mu \mathrm{mol} \mathrm{L}^{-1}$ and from 200 to $90 \mu \mathrm{mol} \mathrm{L}^{-1}$ ) occurred, associated with a large increase in $\delta^{13} \mathrm{C}$-DIC (from $-24.3 \pm 0.03 \%$ to $-18.4 \pm 0.4 \%$ and from $-22.5 \pm 0.2$ to $-14.2 \pm$ $1.2 \%$ ) (Fig. 4).

The results of the two degassing experiments are particularly relevant because they confirm for the first time the experimental validity of the isotope theory (on a very small spatial scale), as the experimental points in the $\delta^{13} \mathrm{C}$-DIC versus DIC (and $\mathrm{pCO}_{2}$ ) plot are very close to the curves computed with the degassing model. Some experimental degassing points slightly differ from theoretical curves in the lower-left part of the model, where a large decrease in DIC occurs with little change in $\delta^{13} \mathrm{C}$-DIC (Fig. 4). This could be due to a less precise analysis of $\delta^{13} \mathrm{C}$-DIC at low DIC concentrations.

\section{Discussion}

\subsection{Origin and temporal variations of DIC in groundwater}

The potential sources of DIC in groundwater are carbonate or silicate weathering and dissolution of soil $\mathrm{CO}_{2}$ that originates from the heterotrophic respiration of soil organic matter (SOM) and from plant root respiration. In addition, heterotrophic respiration occurs also in the saturated zone of the soil, that is, in the ground- 

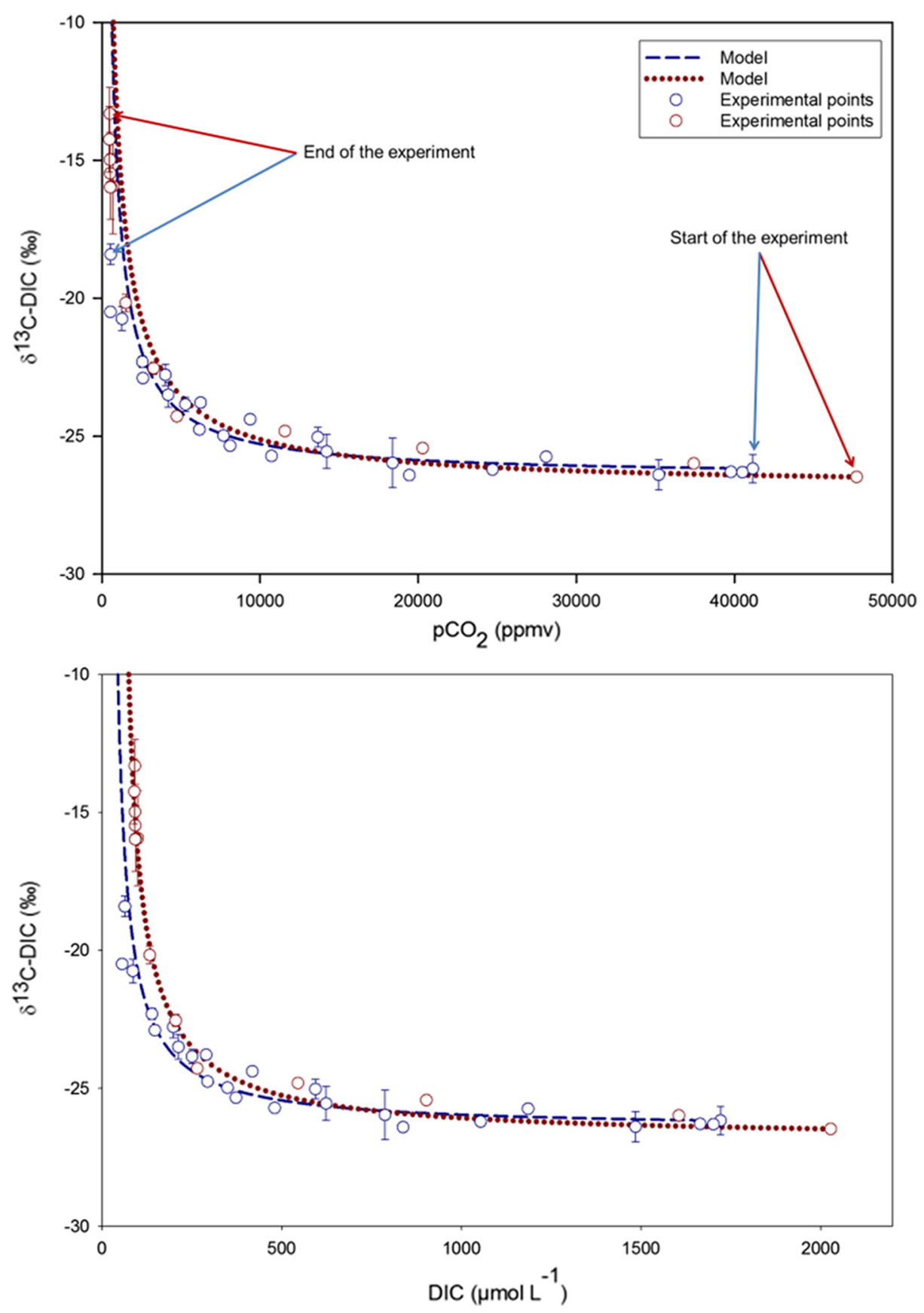

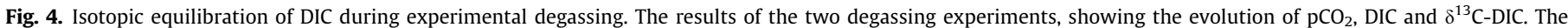
dashed lines show the theoretical degassing model. Note that the total alkalinity (TA) was constant during the experiments.

water itself (Craft et al., 2002). Carbonate weathering produces DIC with a $\delta^{13} \mathrm{C}$ value of approximately half of that of soil $\mathrm{CO}_{2}$, whereas silicate weathering produces DIC with a $\delta^{13} \mathrm{C}$ isotopic composition close to that of soil $\mathrm{CO}_{2}$ (Das et al., 2005; Wachniew, 2006; Polsenaere and Abril, 2012). Vegetation cover in the Leyre watershed is mainly $C_{3}$ plants (i.e., Pinus pinaster) (Govind et al., 2012). The $\delta^{13} \mathrm{C}$ of SOM that originates from $C_{3}$ plants can range between -22 and $-34 \%$ (O'Leary, 1988; Vogel et al., 1993; Diefendorf et al., 2010; Kohn, 2010), with an average value of $-28 \%$. The latter average stable isotope composition of SOM is in agreement with the observations of Polsenaere et al. (2013), who measured an average value for $\delta^{13} \mathrm{C}-\mathrm{POC}$ (particulate organic carbon) of $-28.7 \pm 0.5 \%$ at the outlet of the Leyre River over a one year sampling period. In addition, little or no fractionation occurs during mineralization of
SOM (Amundson et al., 1998; Ekblad et al., 2002). However, due to the selective molecular diffusion of $\mathrm{CO}_{2}$ through the soil pores, the isotopic composition of soil $\mathrm{CO}_{2}$ can become enriched in ${ }^{13} \mathrm{C}$, relative to SOM, by up to $4-5 \%$ o (Cerling et al., 1991; Amundson et al., 1998). Carbon isotopes are also fractionated ( $\varepsilon$ of approximately $-1 \%$ ) during the dissolution of soil $\mathrm{CO}_{2}$ into aqueous $\mathrm{CO}_{2}$ (Zhang et al., 1995). In the sampled groundwater, dissolved $\mathrm{CO}_{2}$ and $\mathrm{HCO}_{3}^{-}$respectively represented $95 \%$ and $5 \%$ of the DIC pool (Table 2).

The average $\delta^{13} \mathrm{C}$-DIC values of $-26.2 \pm 1.2 \%$ observed in groundwater are consistent with two different sources of carbon with the same isotopic signature: (i) aqueous $\mathrm{CO}_{2}$ derived from the respiration of SOM (derived from $\mathrm{C}_{3}$ plants) in soils and groundwater and (ii) $\mathrm{HCO}_{3}^{-}$derived from the soil $\mathrm{CO}_{2}$, which speci- 
ated through water-rock interactions. In addition, aqueous $\mathrm{CO}_{2}$ represented $95 \%$ (range is $76-100 \%$ ) of the DIC in the groundwater, showing the low intensity of silicate weathering. The absence of carbonate weathering in the sampled groundwater is also consistent with the lithology of the sampled groundwater (sands), representative for the majority of the Leyre watershed (Fig. 1). A contribution of carbonate weathering may alter the stable isotope composition of DIC in the groundwater of Miocene carbonated sands located in the most downstream of the watershed, which were not sampled here.

During the monitoring period, seasonal changes in the carbon concentration in groundwater occurred for $\mathrm{pCO}_{2}$ and DIC but not for TA and $\delta^{13} \mathrm{C}$-DIC. This reveals that although the intensity of the DIC source may change over time, the origin of the groundwater DIC remained the same. The lowest values of $\mathrm{pCO}_{2}$ occurred during high flow stages, as a consequence of groundwater dilution with rainwater (Deirmendjian et al., 2017) with a low DIC content (Stumm and Morgan, 1996), which rapidly percolates through the sand (Fig. 2a and b). This is consistent with the sandy texture of the porous soils with a high proportion of coarse sands (Augusto et al., 2010), which makes the infiltration of rain water fast (Vernier and Castro, 2010). In addition, high flow stages are associated with low atmospheric and soil temperature that may lower the soil respiration rate (Lloyd and Taylor, 1994; Kätterer et al., 1998; Epron et al., 1999). Values of $\mathrm{pCO}_{2}$ in groundwater start to increase at the beginning of the base flow period as a consequence of the groundwater DOC (dissolved organic carbon) consumption, which had been leached into the groundwater because the groundwater table had reached the organic horizon during high flow stages (Deirmendjian et al., 2017). During the late summer, the second increase in $\mathrm{pCO}_{2}$ in groundwater originates from soil $\mathrm{CO}_{2}$ that has been transported by simple downward diffusion when the overlying forest ecosystem was in heterotrophic conditions (Deirmendjian et al., 2017).

\subsection{Inorganic carbon processes affecting the isotopic signal of riverine DIC: $\mathrm{CO}_{2}$ degassing versus carbonate weathering}

To analyse qualitatively and quantitatively the process of $\mathrm{CO}_{2}$ degassing and DIC isotopic equilibration with the atmosphere in streams and rivers at the watershed scale, we plotted $\delta^{13} \mathrm{C}$-DIC as a function of $\mathrm{pCO}_{2}$, TA, and DIC (Fig. 5). The distributions of $\delta^{13} \mathrm{C}$ DIC versus $\mathrm{pCO}_{2}$ fit well the trajectories predicted by the degassing model, starting in the groundwater and ending in the fourth-order streams (Fig. 5a).

At the watershed scale, this indicates that degassing is the dominating process that drives the spatial variations of these two parameters and that groundwater enriched in $\mathrm{CO}_{2}$ is the main source of riverine $\mathrm{CO}_{2}$ and DIC. In addition, TA is conservative overall between groundwater, first- and second-order streams (Table 3; Fig. 2c, Fig. 3b; Fig. 5b). Consequently, changes in the $\delta^{13} \mathrm{C}$-DIC between groundwater and second-order streams are attributable only to $\mathrm{CO}_{2}$ evasion to the atmosphere. Furthermore, unlike during experimental degassing (Fig. 4), we never observed very high values of $\mathrm{pCO}_{2}$ with very negative $\delta^{13} \mathrm{C}$-DIC (Table 3; Fig. 5a) in first-order streams, as those found in the groundwater. This suggests that $\mathrm{CO}_{2}$ evasion between groundwater and first-order streams occurs very fast after the water transits from groundwater to surface water. Spring sampling of groundwater and the associated large loss of $\mathrm{pCO}_{2}$ of approximately 21,700 $\pm 6,800 \mathrm{ppmv}$ over $40 \mathrm{~m}$ confirms that degassing from groundwater is a very fast process. This conclusion is in agreement with the findings of Venkiteswaran et al. (2014), who mentioned that most of the $\mathrm{CO}_{2}$ originating from groundwater has been lost before typical in-stream sampling occurs. Öquist et al. (2009) also found in a bor- eal catchment that $65 \%$ of the DIC in the groundwater is lost within $200 \mathrm{~m}$ of the groundwater entering the stream.

To improve the $\mathrm{CO}_{2}$ degassing estimation at the regional scale, especially in lowland areas having shallow groundwater, the value of $\mathrm{pCO}_{2}$ in groundwater should be considered. Our statement agrees with the review of Marx et al. (2017), who highlights that the role of groundwater inputs to streams and their influence on headwaters need to be better characterized. Moreover, it is highly probable that to improve the DIC concentration value of the groundwater entering the stream, future studies will need to sample groundwater (i.e., in piezometer) as close to the stream as possible. Otherwise, the degassing flux would probably be underestimated in such environments.

In the Leyre watershed, changes in $\delta^{13} \mathrm{C}$-DIC between groundwater and second-order streams are almost exclusively due to the degassing of groundwater $\mathrm{CO}_{2}$ and correspond to an increase in $6.9 \pm 2.9 \%$ (Table 3; Fig. 3). As we will discuss later in Section 4.3, although in-stream respiration can occur and liberate ${ }^{13} \mathrm{C}$-depleted DIC in stream waters, its contribution to $\mathrm{CO}_{2}$ degassing is probably minor compared to groundwater $\mathrm{CO}_{2}$ (Hotchkiss et al., 2015). Consequently, DIC in first- and second-order streams can be considered groundwater DIC minus a large part of $\mathrm{CO}_{2}$, which has quickly degassed.

In monolithic watersheds draining only silicate rocks, the TA is typically very low, below $125 \mu \mathrm{mol} \mathrm{L}^{-1}$ according to Meybeck (1987). In the Leyre watershed, although the TA was below this threshold in groundwater and first- and second-order streams, the TA increased in third- and fourth-order streams (Table 3; Fig. 2c, Fig. 3b, Fig. 5b), suggesting a significant contribution of carbonate weathering. The changes in $\delta^{13} \mathrm{C}$-DIC between second- and fourth-order streams were approximately $5.2 \pm 3.6 \%$ (Table 3 ; Fig. 2e; Fig. 3d; Fig. 5), from $-19.3 \pm 2.7 \%$ in second-order streams to $-14.1 \pm 2.4 \%$ in fourth-order streams. This time, the enrichment in ${ }^{13} \mathrm{C}$ is attributable not only to $\mathrm{CO}_{2}$ evasion, as confirmed by the $\mathrm{pCO}_{2}$ decrease (Table 3; Fig. 2b, Fig. 3a, Fig. 5a), but also to inputs of TA from the weathering of carbonates. This increase in TA in fourth-order stream is consistent with the spatial distribution of carbonated sand outcrops dating from Miocene Epoch (Fig. 1). However, the spatial distribution of superficial carbonated sand does not explain the increase in TA in 3rd-order streams. This suggests that the increase of TA is due to deeper groundwater inputs that are in contact with carbonated sand layers (Legigan, 1979; Bertran et al., 2009, Bertran et al., 2011), consistent with the increase in TA and $\delta^{13} \mathrm{C}$-DIC during the base flow period (Fig. 2a and c). As a matter of fact, DIC that originates from the dissolution of carbonate rocks tends to dominate as the major source of alkalinity (Das et al. 2005) and has a strong influence on the isotopic signature of the DIC (Barth et al., 2003), even in watersheds where carbonates are present only in trace amounts.

The $\delta^{13} \mathrm{C}$ values for most carbonates of marine origin is approximately 0\%o (Clark and Fritz, 1997). Carbonates then react with soil $\mathrm{CO}_{2}$ and produce DIC with an isotopic composition close to the averages of soil $\mathrm{CO}_{2}$ and carbonate rocks (Salomons and Mook, 1986), i.e., $-12 \%$ in the Leyre watershed. To differentiate the respective contributions of degassing and carbonate weathering between second- and fourth-order streams, we applied a mixing model between two DIC end-members (Fig. 5b): one endmember is DIC from second-order streams and the other endmember is DIC originating from carbonate weathering with a $\delta^{13} \mathrm{C}$ signature of $-12 \%$ :

$$
\delta^{13} C-D I C_{m m}=\left([D I C]_{2} \times \delta^{13} C-D I C_{2}+x \times \delta^{13} C-D I C_{c a}\right) /\left([D I C]_{2}+x\right)
$$

where $\delta^{13} C-D I C_{m m}$ is the stable isotope composition of DIC resulting from the mixing of the two end-members, $[D I C]_{2}$ and $\delta^{13} C-D I C_{2}$ are 

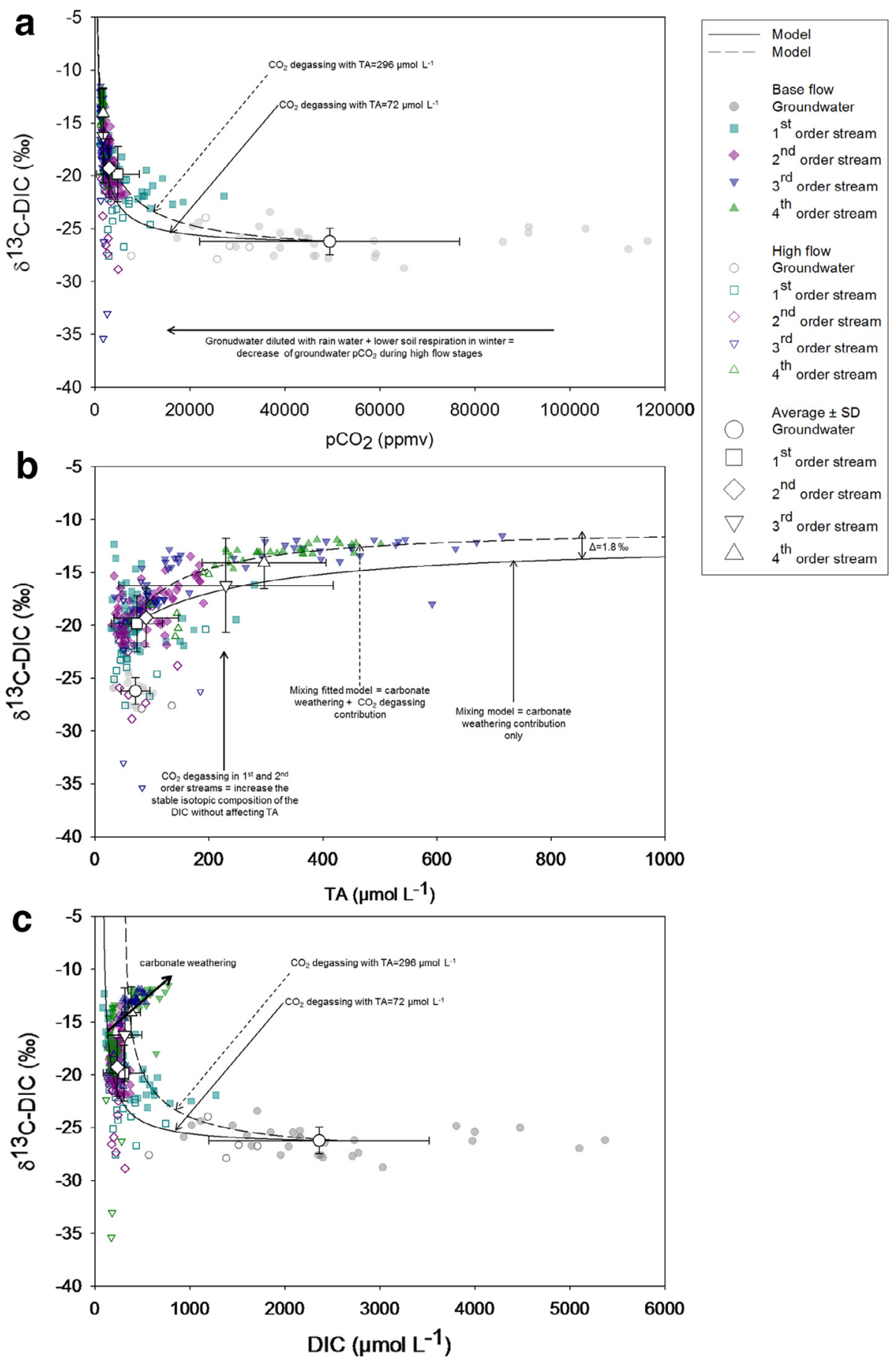

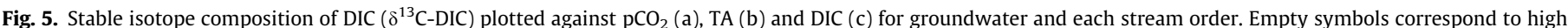

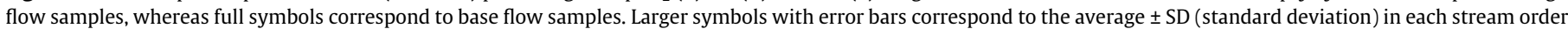

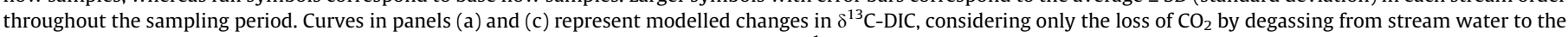

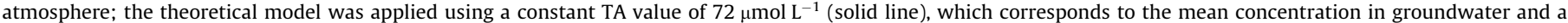

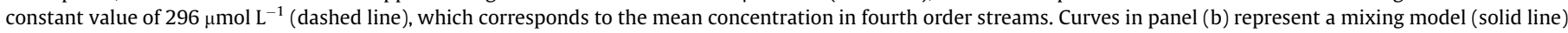

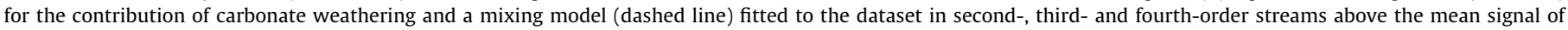
second-order streams $\left(\mathrm{TA}=90 \mu \mathrm{mol} \mathrm{L}^{-1}, \delta^{13} \mathrm{C}\right.$-DIC $=-19.3 \%$ ).

the average composition of second order streams, $\delta^{13} C-D I C_{c a}$ is the average carbon stable isotope composition from carbonate weathering $(-12 \%)$, and $x$ is the fraction of DIC that originates from carbonate weathering.This mixing model does not account for the $\mathrm{CO}_{2}$ loss to the atmosphere and thus predicts the theoretical signature of the DIC as a function of TA, when carbonate weathering occurs, but $\mathrm{CO}_{2}$ degassing does not occur. In addition, we fitted our data of $\delta^{13} \mathrm{C}$-DIC and TA to another curve of the same form as a mixing model (i.e., $f(x)=(A+B \times x) /(C+x))$, without considering a preselected value as an end-member (Fig. $5 b$ ). The $\delta^{13} \mathrm{C}$-DIC and TA values of the second-, third- and fourth-order streams that are above the mean concentration of second order streams (i.e., $\delta^{13} \mathrm{C}$-DIC $=$ $-19.3 \%$ and $\mathrm{TA}=90 \mu \mathrm{mol} \mathrm{L}^{-1}$ ) were used to obtain the fitted curve (Fig. 5b).

In the $\delta^{13} \mathrm{C}$-DIC versus TA plot (Fig. 5b), the fitted curve on our in situ data was well above that given by the carbonate weathering 
mixing model, with a quite constant difference of $-1.8 \%$. This difference in $\delta^{13} \mathrm{C}$-DIC is attributed to $\mathrm{CO}_{2}$ degassing between secondand fourth-order streams, a process accounted for in the fitted curve on the experimental data points but not in the carbonate weathering mixing model. According to these results, between second- and fourth-order streams, inputs of TA from carbonate weathering increase the $\delta^{13} \mathrm{C}$-DIC by $3.4 \%$, whereas $\mathrm{CO}_{2}$ degassing increases it by $1.8 \%$. Thus, in terms of percentages, carbonate weathering explains $65 \%$ of the $\delta^{13} \mathrm{C}$-DIC changes between second- and fourth-order streams, whereas the water-air equilibration explains $35 \%$.

The $\delta^{13} \mathrm{C}$-DIC is an excellent tracer of the dissolved inorganic carbon processes. According to our data, the transport of groundwater DIC followed by degassing in streams of increasing order is the major pathway of $\mathrm{CO}_{2}$ in the Leyre watershed. Indeed, $\mathrm{pCO}_{2}$, DIC and $\delta^{13} \mathrm{C}$-DIC data are explained by the theoretical degassing model between groundwater and second-order streams (Fig. 5ac). In addition, we were also able to separate the effect of evasion on $\mathrm{pCO}_{2}$, DIC and $\delta^{13} \mathrm{C}$-DIC from that of carbonate weathering on TA, DIC and $\delta^{13} \mathrm{C}$-DIC between second- and fourth-order streams (Fig. 5b).

\section{3. $\mathrm{CO}_{2}$ degassing and DIC export at the basin scale}

To estimate $\mathrm{CO}_{2}$ degassing, we apply two independent methods at the scale of the Leyre watershed. The first method consists in a mass balance calculation of $\mathrm{CO}_{2}$ at the basin scale, using water discharge and dissolved $\mathrm{CO}_{2}$ concentrations (Fig. 6); the second method consists of using average measured $\mathrm{pCO}_{2}$ values, stream surface areas, and gas transfer velocities based on hydraulic stream geometric parameters (Raymond et al. 2012). For the first approach, we consider that the loss of $\mathrm{CO}_{2}$ between two different stream orders is due to rapid groundwater $\mathrm{CO}_{2}$ evasion to the atmosphere, as attested by the degassing model that reproduced in situ $\delta^{13} \mathrm{C}$-DIC values well (Fig. 5a). We use the discharge from the groundwater and upstream and the difference in $\mathrm{CO}_{2} *$ between each of the stream orders and the groundwater as follows:

$F_{\text {Or1 }}=Q_{O r 1}\left(\mathrm{CO}_{2_{G W}}^{*}-\mathrm{CO}_{2_{\text {Or1 }}}^{*}\right)$

$$
\begin{aligned}
& F_{\text {Or2 }}=Q_{O r 1}\left(C O_{2_{\text {or } 1}}^{*}-C O_{2_{\text {or } 2}}^{*}\right)+0.45 Q_{O r 2}\left(C_{2_{G W}^{*}}^{*}-C_{2_{\text {Or2 }}}^{*}\right)
\end{aligned}
$$

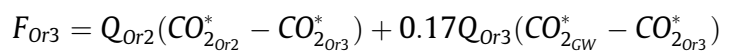

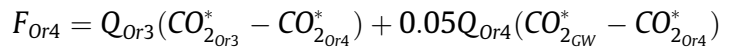

where $F_{O r 1}, F_{O r 2}, F_{O r 3}$ and $F_{O r 4} ; \mathrm{CO}_{2_{G W}}^{*}, \mathrm{CO}_{2_{\text {Or1 }}}^{*}, \mathrm{CO}_{2_{\text {Or }}}^{*}, \mathrm{CO}_{2_{\text {or } 3}^{*}}^{*}$ and $\mathrm{CO}_{2_{\text {Ort }}}^{*}$; $Q_{o r 1}, Q_{o r 2}, Q_{o r 3}$ and $Q_{o r 4}$ are respectively, the degassing flux in mol $\mathrm{s}^{-1}$, the concentration of aqueous- $\mathrm{CO}_{2}$ in $\mathrm{mol} \mathrm{L}^{-1}$ and the river flow in $\mathrm{L} \mathrm{s}^{-1}$, in each stream order.

With this method, we find a total $\mathrm{CO}_{2}$ degassing flux of $1.8 \pm 0.3$ $10^{4} \mathrm{t} \mathrm{C} \mathrm{yr}^{-1}\left(48.2 \pm 7.5 \mathrm{~mol} \mathrm{~s}^{-1}\right)$ from the watershed, with first- and second-order streams accounting respectively for $40 \%$ and $36 \%$ of the total (Table 4; Fig. 6). In addition, it is important to note that the diffusive inputs of groundwater in each of the stream orders are significant in the budget. Indeed, if we assumed that all the discharge measured at the watershed outlet (fourth stream order) was originating from first-order streams (assuming discharge is conservative and groundwater inputs in second-, third- and fourth-order streams are negligible), the total flux of $\mathrm{CO}_{2}$ evasion in the Leyre watershed would be the same, but the contribution of first-order streams would be more than $90 \%$ (compared to $40 \%$ here).

The second method is based on the stream surface area, the water-air gradient and the gas transfer velocity. Stream hydraulic parameters ( W, D, V) modelled with empirical equations from Raymond et al. (2012) were relatively consistent with field measurements at the sampling stations (Table 1 ), which suggests that the calculated $\mathrm{k}_{600}$ are robust. This second method gave a total degassing flux of $1.5 \pm 0.510^{4} \mathrm{t} \mathrm{C} \mathrm{yr}^{-1}\left(38.5 \pm 14.1 \mathrm{~mol} \mathrm{~s}^{-1}\right)$, which is $25 \%$ lower than that from method 1 .

$\mathrm{CO}_{2}$ degassing fluxes and $\mathrm{k}_{600}$ values obtained with the two independent methods were very consistent for stream orders 2,3 and 4 , but fluxes from the hydrological mass balance (method 1) were $83 \%$ higher for first-order streams. This suggests that in very small streams, the conventional method based on surface area and gas transfer velocity (method 2) may underestimate degassing. This could be due to the hotspot character of $\mathrm{CO}_{2}$ evasion and the very fast degassing at the groundwater-stream interface that

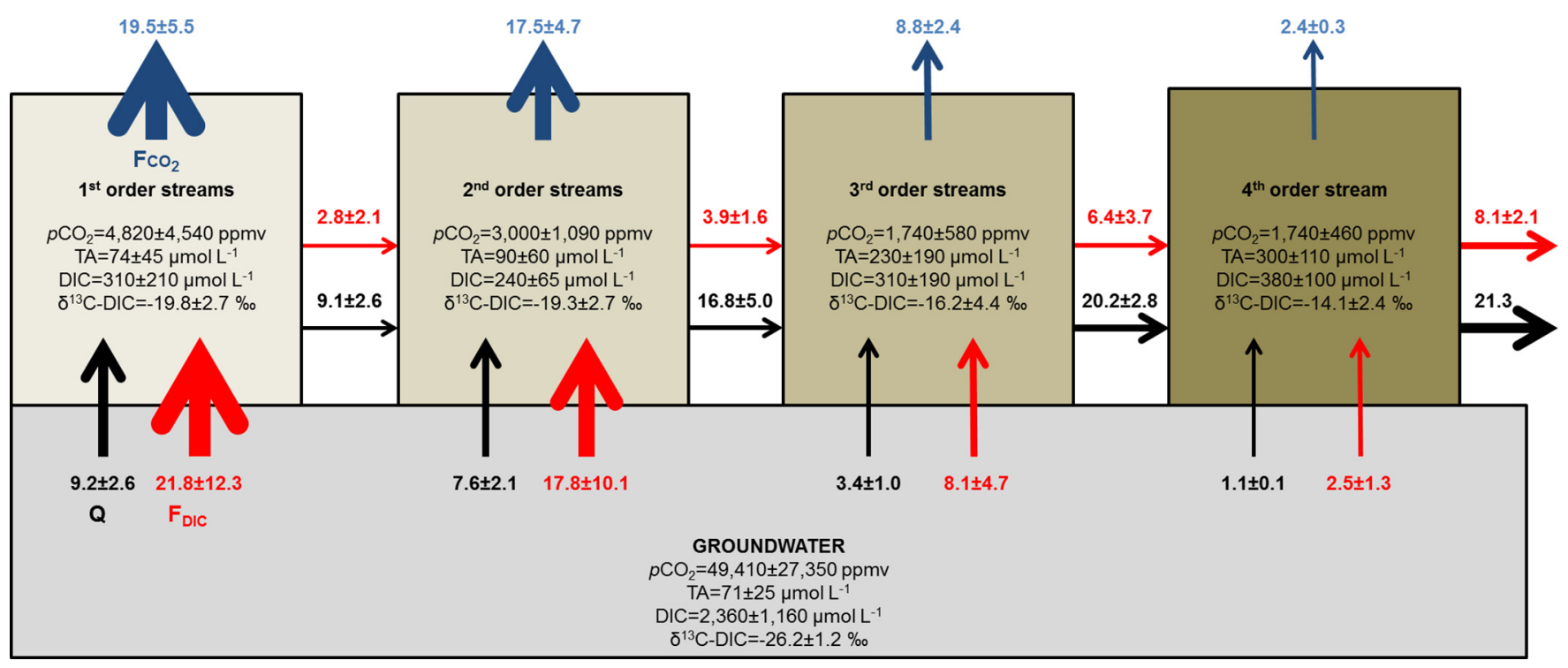

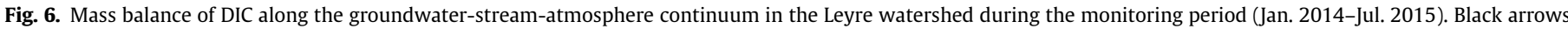

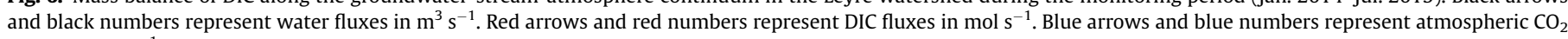

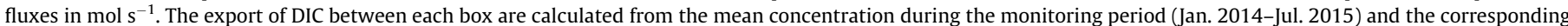

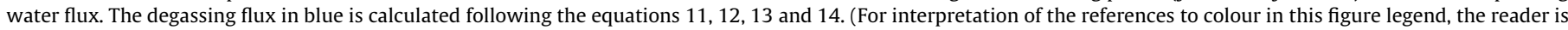
referred to the web version of this article.) 
Table 4

Water discharge and $\mathrm{CO}_{2}$ degassing fluxes in each stream order in the Leyre watershed.

\begin{tabular}{|c|c|c|c|c|}
\hline Stream Orders & $1^{\text {st }}$ & $2^{\text {nd }}$ & $3^{\text {rd }}$ & $4^{\text {th }}$ \\
\hline \multicolumn{5}{|l|}{ Method 1} \\
\hline \multicolumn{5}{|l|}{ Water discharge $\left(\mathrm{m}^{3} \mathrm{~s}^{-1}\right)$} \\
\hline From groundwater & $9.2 \pm 2.6$ & $7.6 \pm 2.1$ & $3.4 \pm 1.0$ & $1.1 \pm 0.1$ \\
\hline From upstream & 0 & $9.2 \pm 2.6$ & $16.8 \pm 5.0$ & $20.2 \pm 2.8$ \\
\hline Total & $9.2 \pm 2.6$ & $16.8 \pm 5.0$ & $20.2 \pm 2.8$ & 21.3 \\
\hline \multicolumn{5}{|l|}{$\Delta C O_{2}^{*}\left(\mu \mathrm{mol} \mathrm{L} L^{-1}\right)$} \\
\hline With groundwater & 2,112 & 2,203 & 2,265 & 2,266 \\
\hline With upstream & & 91 & 62 & 1 \\
\hline \multicolumn{5}{|l|}{$\mathrm{CO}_{2}^{*}$ degassing flux $\left(\mathrm{mol} \mathrm{s}^{-1}\right)$} \\
\hline From groundwater & $19.5 \pm 5.4$ & $16.6 \pm 4.7$ & $7.8 \pm 2.3$ & $2.4 \pm 0.3$ \\
\hline From upstream & 0 & $0.9 \pm 0.2$ & $1.0 \pm 0.3$ & $0.02 \pm 0.002$ \\
\hline Total & $19.5 \pm 5.4$ & $17.5 \pm 4.7$ & $8.8 \pm 2.4$ & $2.4 \pm 0.3$ \\
\hline Contribution to the total (\%) & 40 & 36 & 18 & 6 \\
\hline Aerial $\mathrm{CO}_{2}$ flux ${ }^{\mathrm{a}}\left(\mu \mathrm{mol} \mathrm{m} \mathrm{m}^{-2} \mathrm{~s}^{-1}\right)$ & $5.5 \pm 2.2$ & $3.3 \pm 1.3$ & $2.3 \pm 0.7$ & $1.3 \pm 0.3$ \\
\hline $\mathrm{k}^{\mathrm{b}}\left(\mathrm{m} \mathrm{d}^{-1}\right)$ & $2.2 \pm 2.1$ & $2.3 \pm 1.2$ & $3.0 \pm 1.3$ & $1.8 \pm 0.7$ \\
\hline $\mathrm{k}_{600}\left(\mathrm{~m} \mathrm{~d}^{-1}\right)$ & $2.6 \pm 2.5$ & $2.7 \pm 1.4$ & $3.6 \pm 1.6$ & $2.1 \pm 0.8$ \\
\hline \multicolumn{5}{|l|}{ Method 2} \\
\hline Surface area & $3.5 \pm 1.0$ & $5.3 \pm 1.6$ & $3.9 \pm 0.5$ & $1.9 \pm 0.3$ \\
\hline$\Delta \mathrm{pCO}_{2}(\mu \mathrm{atm})$ & 4,420 & 2,600 & 1,340 & 1,340 \\
\hline $\mathrm{k}_{600}^{\mathrm{c}}\left(\mathrm{m} \mathrm{d}^{-1}\right)$ & $1.2 \pm 0.6$ & $1.9 \pm 0.4$ & $3.4 \pm 0.8$ & $2.1 \pm 0.5$ \\
\hline Aerial $\mathrm{CO}_{2}$ flux $\left(\mu \mathrm{mol} \mathrm{m}{ }^{-2} \mathrm{~s}^{-1}\right)$ & $3.0 \pm 1.1$ & $2.8 \pm 0.6$ & $2.5 \pm 0.5$ & $1.5 \pm 0.5$ \\
\hline $\mathrm{CO}_{2}^{*}$ degassing flux $\left(\mathrm{mol} \mathrm{s}^{-1}\right)$ & $10.6 \pm 10.5$ & $15.1 \pm 7.6$ & $9.9 \pm 4.2$ & $2.8 \pm 1.2$ \\
\hline Contribution to the total (\%) & 28 & 39 & 26 & 7 \\
\hline
\end{tabular}

a Calculated as the degassing flux divided by the water surface area.

${ }^{\mathrm{b}}$ For method $1, \mathrm{k}$ was calculated as the degassing flux divided by the water stream area and the water-air gradient $\left(\right.$ with $\mathrm{pCO}_{2}$ air $\left.=400 \mathrm{ppmv}\right)$.

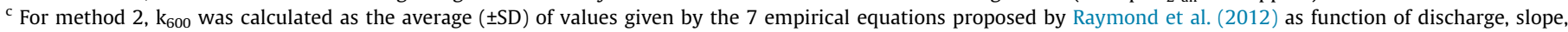
velocity, and/or depth.

cannot be obtained with conventional stream sampling. This hypothesis was confirmed by our observations in spring water that lost $70 \%$ of its $\mathrm{CO}_{2} 40 \mathrm{~m}$ downstream.

Another important question that must be carefully considered when comparing the two methods is the contribution of in-stream $\mathrm{CO}_{2}$ production (i.e., respiration and photooxidation) to degassing. Indeed, when groundwater DOC enters the superficial river network through drainage, part of it might be rapidly recycled by photooxidation (e.g., Macdonald and Minor, 2013; Moody and Worrall, 2016) and by respiration within the stream (e.g., Roberts et al., 2007; Hall et al., 2016). Method 1 is based on the mass balance calculation and assumes that all the $\mathrm{CO}_{2}$ originates from the groundwater, whereas method 2 is based on gas transfer velocity and accounts for all the $\mathrm{CO}_{2}$ outgassed from the streams: the $\mathrm{CO}_{2}$ from the groundwater and the $\mathrm{CO}_{2}$ produced by in-stream $\mathrm{CO}_{2}$ production (Battin et al., 2008; Hotchkiss et al., 2015). The fact that method 1 (that neglects in-stream respiration) gives a $\mathrm{CO}_{2}$ degassing flux higher than that with method 2 suggests that in-stream $\mathrm{CO}_{2}$ production is within the uncertainty of the two methods and a minor component of $\mathrm{CO}_{2}$ degassing in the Leyre watershed. In their analysis of rivers of different sizes, Hotchkiss et al. (2015) reported an average contribution of in-stream net heterotrophy of $14 \%$ of the $\mathrm{CO}_{2}$ degassing of US streams with discharges lower than $0.01 \mathrm{~m}^{3} \mathrm{~s}^{-1}$. In the case of the Leyre River basin, measurements of metabolic activity in very shallow water depths of first-order streams are missing. In addition, a significant part of the in-stream respiration may be benthic, using litter from riparian vegetation.

To close a DIC budget for the Leyre watershed (Table 5, Fig. 6), we also calculated the export of carbon to Arcachon Bay at the most downstream gauging station using annual mean DIC concentration and annual mean river flow. As $\mathrm{pCO}_{2}$ at this downstream station was still far from the equilibrium with the atmosphere, $18 \%$ the DIC input to the coastal bay was in the form of excess $\mathrm{CO}_{2}$. Excess $\mathrm{CO}_{2}$, as defined as the quantity of DIC that is transferred as $\mathrm{CO}_{2}$ to the atmosphere after complete water-air equilibration (Abril et al., 2000), was calculated as the difference between in situ DIC (i.e., calculated with in situ TA, $\mathrm{pCO}_{2}$ and temperature) and a theoretical calculated DIC at equilibrium with the atmosphere (400 ppmv). Excess $\mathrm{CO}_{2}$ will be rapidly degassed in Arcachon Bay. In total, the terrestrial ecosystem in the Leyre watershed exports an average of $56.3 \pm 7.9 \mathrm{~mol} \mathrm{~s}^{-1}$ as DIC to surface waters. Among this total flux, $85 \%$ returns to the atmosphere from the stream surface as $\mathrm{CO}_{2}, 3 \%$ potentially degases in Arcachon Bay and $12 \%$ is exported as alkalinity to the coastal bay (Table 5).

Table 5

DIC budget of the Leyre watershed. Fluxes are given as absolute numbers ( $\mathrm{mol} \mathrm{s}^{-1}$ ) or as normalized to the surface area of the entire watershed $\left(\mathrm{g} \mathrm{C}^{-2} \mathrm{yr}^{-1}\right)$.

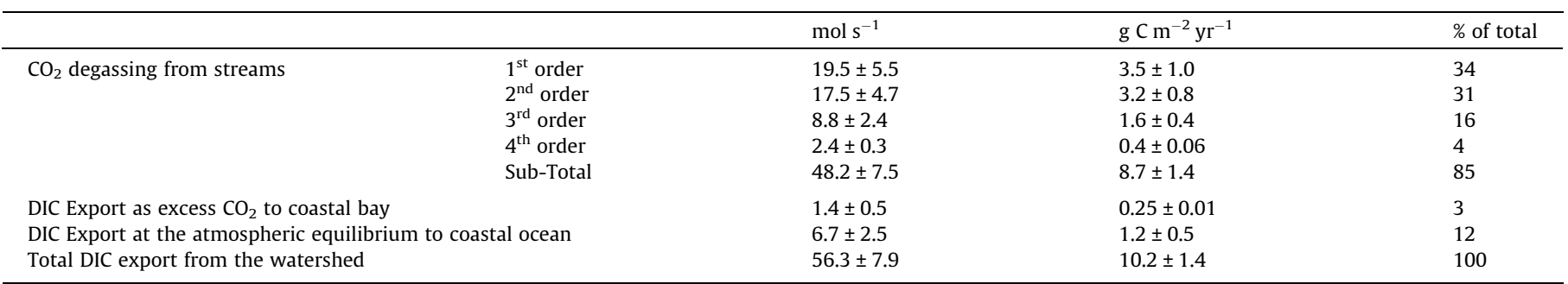




\section{Conclusion}

Monitoring $\mathrm{pCO}_{2}$, TA, and DIC concentrations as well as the stable isotope signature of the DIC in groundwater and surface waters of the Leyre catchment brings new insights to the nature of the mechanisms that control $C$ degassing to the atmosphere. The groundwater-stream-atmosphere interface behaves as a hotspot of $\mathrm{C}$ at our study site. Groundwater inputs enriched in $\mathrm{CO}_{2}$ (i.e., resulting from soil and groundwater respiration) in surface waters are the major source of $\mathrm{CO}_{2}$ evasion and in-stream processes are a minor component of the $\mathrm{CO}_{2}$ evasion. This degassing leads to an enrichment of the riverine stable isotope signature of the DIC along the river courses, and in the case of silicatedominated river, it could be reproduced by an isotopic degassing model. Our DIC, TA and $\delta^{13} \mathrm{C}$-DIC data also enabled us to quantify the relative importance of gas exchange and carbonate weathering along the river course with increasing stream orders. Indeed, in third- and fourth-order streams, carbonate weathering also contributed to the ${ }^{13} \mathrm{C}$ enrichment of DIC downstream. However, our methodology shall only be applied in acidic rivers where carbonates are present in minor proportion.

To calculate a $\mathrm{CO}_{2}$ mass balance of the Leyre watershed, we used a classical method based on stream hydrology and geometry, water $\mathrm{pCO}_{2}$, water surface area, and gas transfer velocity. We compared this method with another original hydrological method that calculates the loss of the dissolved $\mathrm{CO}_{2}$ between groundwater and each stream order using $\mathrm{CO}_{2}$ concentrations and drainages data. The two methods give consistent results, except in first-order streams where the classical method based on water $\mathrm{pCO}_{2}$ and gas transfer velocity apparently missed some $\mathrm{CO}_{2}$ emission hotspots in the headwaters. Thus, in future studies, direct sampling of groundwater $\mathrm{pCO}_{2}$ associated with the estimation of groundwater discharge are needed for a better evaluation of $\mathrm{CO}_{2}$ losses from streams and rivers, especially in lowland areas having shallow groundwater. Evasion of $\mathrm{CO}_{2}$ from first- and second-order streams was the dominant component of the entire DIC flux in the watershed, accounting for approximately $75 \%$ of the total $\mathrm{CO}_{2}$ evasion flux from the river network. Overall, $\mathrm{CO}_{2}$ evasion from the river system represents $85 \%$ of the entire DIC export from the Leyre watershed. The remaining part is alkalinity (mainly from carbonate weathering downstream) and some excess $\mathrm{CO}_{2}$ that are exported to Arcachon Bay.

\section{Acknowledgments}

This research is part of the CNP-Leyre project funded by the Cluster of Excellence COTE at the Universite de Bordeaux (ANR10-LABX-45). We thank the two reviewers, Johannes Barth and Guillaume Bertrand for their helpful and constructive comments. We thank Dominique Poirier, Luiz Carlos Cotovicz Junior, Katixa Lajaunie-Salla, Baptiste Voltz, Gwenaëlle Chaillou and Damien Buquet (EPOC Bordeaux) for their assistance in the field. Karine Charlier and Céline Charbonnier helped with chemical and isotopic analysis; Christophe Chipeaux and Denis Loustau (ISPA, INRA Bordeaux) provided water table data and Bernard Gaillard (DIREN Aquitaine) provided river discharge chronic.

\section{Appendix A. Supplementary data}

Supplementary data associated with this article can be found, in the online version, at https://doi.org/10.1016/j.jhydrol.2018.01. 003.

\section{References}

Abril, G., Bouillon, S., Darchambeau, F., Teodoru, C.R., Marwick, T.R., Tamooh, F., Ochieng Omengo, F., Geeraert, N., Deirmendjian, L., Polsenaere, P., Borges, A.V. 2015. Technical Note: large overestimation of pCO2 calculated from pH and alkalinity in acidic, organic-rich freshwaters. Biogeosciences $12,67-78$. https:// doi.org/10.5194/bg-12-67-2015.

Abril, G., Etcheber, H., Borges, A.V., Frankignoulle, M., 2000. Excess atmospheric carbon dioxide transported by rivers into the Scheldt estuary. Comptes Rendus de l'Academie des Sciences-Series IIA-Earth and Planetary Science 330, 761768.

Amiotte-Suchet, P., Probst, J.-L., Ludwig, W., 2003. Worldwide distribution of continental rock lithology: implications for the atmospheric/soil $\mathrm{CO} 2$ uptake by continental weathering and alkalinity river transport to the oceans. Global Biogeochem. Cycles 17.

Amundson, R., Stern, L., Baisden, T., Wang, Y., 1998. The isotopic composition of soil and soil-respired CO 2. Geoderma 82, 83-114.

Augusto, L., Bakker, M.R., Morel, C., Meredieu, C., Trichet, P., Badeau, V., Arrouays, D. Plassard, C., Achat, D.L., Gallet-Budynek, A., Merzeau, D., Canteloup, D., Najar M., Ranger, J., 2010. Is "grey literature" a reliable source of data to characterize soils at the scale of a region? A case study in a maritime pine forest in southwestern France. Eur. J. Soil Sci. 61, 807-822. https://doi.org/10.1111/ j.1365-2389.2010.01286.x.

Barth, J.A.C., Cronin, A.A., Dunlop, J., Kalin, R.M., 2003. Influence of carbonates on the riverine carbon cycle in an anthropogenically dominated catchment basin: evidence from major elements and stable carbon isotopes in the Lagan River ( $\mathrm{N}$ Ireland). Chem. Geol. 200, 203-216.

Battin, T.J., Kaplan, L.A., Findlay, S., Hopkinson, C.S., Marti, E., Packman, A.I., Newbold, J.D., Sabater, F., 2008. Biophysical controls on organic carbon fluxes in fluvial networks 595595 Nat. Geosci 2. https://doi.org/10.1038/ngeo602.

Bertran, P., Allenet, G., Gé, T., Naughton, F., Poirier, P., Goñi, M.F.S., 2009. Coversand and pleistocene palaeosols in the landes region, southwestern france. J. Quaternary Sci. 24, 259-269.

Bertran, P., Bateman, M.D., Hernandez, M., Mercier, N., Millet, D., Sitzia, L., Tastet, J.P., 2011. Inland aeolian deposits of south-west France: facies, stratigraphy and chronology. J. Quaternary Sci. 26, 374-388.

Borges, A.V., 2005. Do we have enough pieces of the jigsaw to integrate CO2 fluxes in the coastal ocean? Estuaries 28, 3-27.

Brunet, F., Gaiero, D., Probst, J.-L., Depetris, P.J., Gauthier Lafaye, F., Stille, P., 2005. $\delta 13 \mathrm{C}$ tracing of dissolved inorganic carbon sources in Patagonian rivers (Argentina). Hydrological Processes 19, 3321-3344.

Butman, D., Raymond, P.A., 2011. Significant efflux of carbon dioxide from streams and rivers in the United States. Nat. Geosci 4, 839-842. https://doi.org/10.1038/ ngeo1294.

Cai, W.-J., Guo, X., Chen, C.-T.A., Dai, M., Zhang, L., Zhai, W., Lohrenz, S.E., Yin, K., Harrison, P.J., Wang, Y., 2008. A comparative overview of weathering intensity and HCO 3-flux in the world's major rivers with emphasis on the Changjiang, Huanghe, Zhujiang (Pearl) and Mississippi Rivers. Continental Shelf Res. 28, $1538-1549$.

Cerling, T.E., Solomon, D.K., Quade, J., Bowman, J.R., 1991. On the isotopic composition of carbon in soil carbon dioxide. Geochimica et Cosmochimica Acta 55, 3403-3405.

Ciais, P., Sabine, C., Bala, G., Bopp, L., Brovkin, V., Canadell, J., Chhabra, A., DeFries, R. Galloway, J., Heimann, M., Jones, C., Le Quéré, C., Myeni, R., Piao, S., Thornton, P. 2013. Carbon and other biogeochemical cycles, in: Climate Change 2013: The Physical Science Basis. Contribution of Working Group I to the Fifth Assessment Report of the Intergovernmental Panel on Climate Change. Cambridge University Press, Cambridge, United Kingdom and New York, NY, USA, pp. 465-570.

Clark, I., Fritz, P., 1997. Environmental Isotopes in Hydrology. Lewis Publishers, Boca Raton, Fla.

Cole, J.J., Caraco, N.F., 2001. Carbon in catchments: connecting terrestrial carbon losses with aquatic metabolism. Mar. Freshwater Res. 52, 101-110.

Cole, J.J., Prairie, Y.T., Caraco, N.F., McDowell, W.H., Tranvik, L.J., Striegl, R.G., Duarte, C.M., Kortelainen, P., Downing, J.A., Middelburg, J.J., Melack, J., 2007. Plumbing the global carbon cycle: integrating inland waters into the terrestrial carbon budget. Ecosystems 10, 171-184. https://doi.org/10.1007/s10021-006-9013-8.

Corbier, P., Karnay, G., Bourgine, B., Saltel, M., 2010. Gestion des eaux souterraines en région Aquitaine. Reconnaissance des potentialités aquiferes du Mio-PlioQuaternaire des Landes de Gascogne et du Médoc en relation avec les SAGE. No. Rapport final, BRGM RP 57813.

Craft, J.A., Stanford, J.A., Pusch, M., 2002. Microbial respiration within a floodplain aquifer of a large gravel-bed river. Freshwater Biol. 47, 251-261.

Das, A., Krishnaswami, S., Bhattacharya, S.K., 2005. Carbon isotope ratio of dissolved inorganic carbon (DIC) in rivers draining the Deccan Traps, India: sources of DIC and their magnitudes. Earth Planetary Sci. Lett. 236, 419-429.

Davidson, E.A., Figueiredo, R.O., Markewitz, D., Aufdenkampe, A.K., 2010. Dissolved $\mathrm{CO} 2$ in small catchment streams of eastern Amazonia: a minor pathway of terrestrial carbon loss. J. Geophys. Res.: Biogeosci., 115

Degens, E., Kempe, S., Richey, J.E., 1991. Chapter 15, summary Biogeochemistry of major world rivers. In: Degend, E.T., Kempe, S., Richey, J.E. (Eds.) Biogeochemestry of major world river. Scope 42. Wiley, New York, pp. 323-344.

Deirmendjian, L., Loustau, D., Augusto, L., Lafont, S., Chipeaux, C., Poirier, D., Abril, G., 2017. Hydrological and ecological controls on dissolved carbon concentrations in groundwater and carbon export to surface waters in a 
temperate pine forest watershed. Biogeosci. Discuss. 2017, 1-34. https://doi. org/10.5194/bg-2017-90.

Diefendorf, A.F., Mueller, K.E., Wing, S.L., Koch, P.L., Freeman, K.H., 2010. Global patterns in leaf $13 \mathrm{C}$ discrimination and implications for studies of past and future climate. Proc. Natl. Acad. Sci. 107, 5738-5743.

Doctor, D.H., Kendall, C., Sebestyen, S.D., Shanley, J.B., Ohte, N., Boyer, E.W., 2008. Carbon isotope fractionation of dissolved inorganic carbon (DIC) due to outgassing of carbon dioxide from a headwater stream. Hydrological Processes 22, 2410-2423.

Downing, J.A., Cole, J.J., Duarte, C.M., Middelburg, J.J., Melack, J.M., Prairie, Y.T., Kortelainen, P., Striegl, R.G., McDowell, W.H., Tranvik, L.J., 2012. Globa abundance and size distribution of streams and rivers. Inland waters 2, 229236.

EEA, 2014. Corine Land Cover 2006 raster data. European Environment Agency (EEA), available at: http://www. eea. europa. eu/data-and-maps/data/ ds_resolveuid/a645109f7a11d43f5d7e275d81f35c61 3.

Ekblad, A., Nyberg, G., Högberg, P., 2002. 13C-discrimination during microbial respiration of added C3-, C4-and 13C-labelled sugars to a C3-forest soil. Oecologia 131, 245-249.

Epron, D., Etitia, L., Farque, Lucot, É., Badot, P.-M., 1999. Soil CO2 efflux in a beech forest: dependence on soil temperature and soil water content. Ann. Forest Sci. 56, 221-226.

Frankignoulle, M., Borges, A.V., 2001. Direct and indirect pCO2 measurements in a wide range of pCO2 and salinity values (The Scheldt Estuary). Aquatic Geochem. 7, 267-273. https://doi.org/10.1023/A:1015251010481.

Frankignoulle, M., Bourge, I., Wollast, R., 1996. Atmospheric CO2 fluxes in a highly polluted estuary (the Scheldt). Limnol. Oceanography.

Gillikin, D.P., Bouillon, S., 2007. Determination of $\delta 180$ of water and $\delta 13 C$ of dissolved inorganic carbon using a simple modification of an elementa analyser-isotope ratio mass spectrometer: an evaluation. Rapid Commun. Mass Spectrometry 21, 1475-1478.

Govind, A., Bonnefond, J.-M., Kumari, J., Moisy, C., Loustau, D., Wigneron, J.-P., 2012 Modeling the ecohydrological processes in the Landes de Gascogne. In: France, S.W. (Ed.), Plant Growth Modeling, Simulation, Visualization and Applications (PMA). 2012 IEEE Fourth International Symposium on. IEEE, pp. 133-140.

Gran, G., 1952. Determination of the equivalence point in potentiometric titrations of seawater with hydrochloric acid. Oceanol. Acta 5, 209-218.

Hall Jr, R.O., Tank, J.L., Baker, M.A., Rosi-Marshall, E.J., Hotchkiss, E.R., 2016. Metabolism, gas exchange, and carbon spiraling in rivers. Ecosystems 19, 73

Hartmann, J., Lauerwald, R., Moosdorf, N., 2014. A brief overview of the GLOba RIver CHemistry Database, GLORICH. Procedia Earth Planetary Sci. 10, 23-27.

Hotchkiss, E.R., Hall Jr, R.O., Sponseller, R.A., Butman, D., Klaminder, J., Laudon, H. Rosvall, M., Karlsson, J., 2015. Sources of and processes controlling CO2 emissions change with the size of streams and rivers. Nat. Geosci. 8, 696-699.

Johnson, M.S., Lehmann, J., Riha, S.J., Krusche, A.V., Richey, J.E., Ometto, J.P.H., Couto E.G., 2008. CO2 efflux from Amazonian headwater streams represents a significant fate for deep soil respiration. Geophys. Res. Lett. 35.

Jolivet, C., Augusto, L., Trichet, P., Arrouays, D., 2007. Forest soils in the Gascony Landes Region: formation, history, properties and spatial varaibility [WWW Document]. URL http://hdl.handle.net/2042/8480.

Kätterer, T., Reichstein, M., Andrén, O., Lomander, A., 1998. Temperature dependence of organic matter decomposition: a critical review using literature data analyzed with different models. Biol. Fertility Soils 27, 258-262.

Kohn, M.J., 2010. Carbon isotope compositions of terrestrial C3 plants as indicators of (paleo) ecology and (paleo) climate. Proc. Natl. Acad. Sci. 107, 19691-19695.

Kokic, J., Wallin, M.B., Chmiel, H.E., Denfeld, B.A., Sobek, S., 2015. Carbon dioxide evasion from headwater systems strongly contributes to the total export of carbon from a small boreal lake catchment. J. Geophys. Res.: Biogeosci. 120. https://doi.org/10.1002/2014JG002706.

Lauerwald, R., Hartmann, J., Moosdorf, N., Kempe, S., Raymond, P.A., 2013. What controls the spatial patterns of the riverine carbonate system? - a case study for North America. Chem. Geol. 337, 114-127.

Legigan, P., 1979. L'élaboration de la formation du sable des Landes, dépôt résiduel de l'environnement sédimentaire pliocène-pléïstocène centre aquitain. Institut de géologie du Bassin d'Aquitaine.

Lewis, E., Wallace, D., Allison, L.J., 1998. Program developed for $\mathrm{CO}_{2}$ system calculations. Carbon Dioxide Information Analysis Center, managed by Lockheed Martin Energy Research Corporation for the US Department of Energy Tennessee.

Lloyd, J., Taylor, J.A., 1994. On the temperature dependence of soil respiration. Funct. Ecol., 315-323

Ludwig, W., Amiotte-Suchet, P., Munhoven, G., Probst, J.-L., 1998. Atmospheric CO2 consumption by continental erosion: present-day controls and implications for the last glacial maximum. Global Planetary Change 16, 107-120.
Macdonald, M.J., Minor, E.C., 2013. Photochemical degradation of dissolved organic matter from streams in the western Lake Superior watershed. Aquatic Sci. 75 509-522.

Marx, A., Dusek, J., Jankovec, J., Sanda, M., Vogel, T., Geldern, R., Hartmann, J., Barth, J.A.C., 2017. A review of $\mathrm{CO} 2$ and associated carbon dynamics in headwater streams: a global perspective. Rev. Geophys.

Meybeck, M., 1987. Global chemical weathering of surficial rocks estimated from river dissolved loads. Am. J. Sci., 401-428

Millero, F.J., 1979. The thermodynamics of the carbonate system in seawater. Geochimica et Cosmochimica Acta 43, 1651-1661.

Miyajima, T., Miyajima, Y., Hanba, Y.T., Yoshii, K., Koitabashi, T., Wada, E., 1995. Determining the stable isotope ratio of total dissolved inorganic carbon in lake water by GC/C/IIRMS. Limnol. Oceanography 40, 994-1000.

Moody, C.S., Worrall, F., 2016. Sub-daily rates of degradation of fluvial carbon from a peat headwater stream. Aquatic Sci. 78, 419-431.

Moreaux, V., Lamaud, É., Bosc, A., Bonnefond, J.-M., Medlyn, B.E., Loustau, D., 2011. Paired comparison of water, energy and carbon exchanges over two young maritime pine stands (Pinus pinaster Ait.): effects of thinning and weeding in the early stage of tree growth. Tree physiology tpr048.

O'Leary, M.H., 1988. Carbon isotopes in photosynthesis. Bioscience, 328-336.

Öquist, M.G., Wallin, M., Seibert, J., Bishop, K., Laudon, H., 2009. Dissolved inorganic carbon export across the soil/stream interface and its fate in a boreal headwater stream. Environ. Sci. Technol. 43, 7364-7369.

Polsenaere, P., Abril, G., 2012. Modelling CO2 degassing from small acidic rivers using water pCO2, DIC and 813 C-DIC data. Geochimica et Cosmochimica Acta 91, 220-239. https://doi.org/10.1016/j.gca.2012.05.030.

Polsenaere, P., Savoye, N., Etcheber, H., Canton, M., Poirier, D., Bouillon, S., Abril, G., 2013. Export and degassing of terrestrial carbon through watercourses draining a temperate podzolized catchment. Aquatic Sci. 75, 299-319.

Raymond, P.A., Hartmann, J., Lauerwald, R., Sobek, S., McDonald, C., Hoover, M., Butman, D., Striegl, R., Mayorga, E., Humborg, C., Kortelainen, P., Dürr, H., Meybeck, M., Ciais, P., Guth, P., 2013. Global carbon dioxide emissions from inland waters. Nature 503, 355-359. https://doi.org/10.1038/nature12760.

Raymond, P.A., Zappa, C.J., Butman, D., Bott, T.L., Potter, J., Mulholland, P., Laursen, A. E., McDowell, W.H., Newbold, D., 2012. Scaling the gas transfer velocity and hydraulic geometry in streams and small rivers. Limnol. Oceanography: Fluids Environ. 2, 41-53.

Roberts, B.J., Mulholland, P.J., Hill, W.R., 2007. Multiple scales of temporal variability in ecosystem metabolism rates: results from 2 years of continuous monitoring in a forested headwater stream. Ecosystems 10, 588-606.

Salomons, W., Mook, W.G., 1986. Isotope geochemistry of carbonates in the weathering zone. Handbook Environ. Isotope Geochem. 2, 239-269.

Stallard, R.F., 1998. Terrestrial sedimentation and the carbon cycle: coupling weathering and erosion to carbon burial. Global Biogeochem. Cycles 12, 231257.

Stumm, W., Morgan, J.J., 1996. Chemical equilibria and rates in natural waters. Aquatic Chem., 521-531

Thivolle-Cazat, A., Najar, M., 2001. Évolution de la productivité et de la récolte du pin maritime dans le massif Landais. Evaluation de la disponibilité future en Gironde. Revue forestière française 53, 351-355.

Venkiteswaran, J.J., Schiff, S.L., Wallin, M.B., 2014. Large carbon dioxide fluxes from headwater boreal and sub-boreal streams. PLoS One 9, e101756. https://doi.org/ 10.1371 /journal.pone.0101756.

Vernier, F., Castro, A., 2010. Critère Préservation de l'environnement Sous-critère Eau.

Vidon, P., Allan, C., Burns, D., Duval, T.P., Gurwick, N., Inamdar, S., Lowrance, R., Okay, J., Scott, D., Sebestyen, S., 2010. Hot spots and hot moments in riparian zones: Potential for improved water quality management. Wiley Online Library.

Vogel, J.C., Ehleringer, J.R., Hall, A.E., Farquhar, G.D., 1993. Variability of carbon isotope fractionation during photosynthesis. In: Stable Isotopes and Plant Carbon-Water Relations. Academic Press Inc., pp. 29-46.

Wachniew, P., 2006. Isotopic composition of dissolved inorganic carbon in a large polluted river: the Vistula, Poland. Chem. Geol. 233, 293-308.

Wallin, M.B., Grabs, T., Buffam, I., Laudon, H., Ågren, A., Öquist, M.G., Bishop, K., 2013. Evasion of $\mathrm{CO} 2$ from streams - the dominant component of the carbon export through the aquatic conduit in a boreal landscape. Glob Change Biol. 19, 785-797. https://doi.org/10.1111/gcb.12083.

Weiss, R., 1974. Carbon dioxide in water and seawater: the solubility of a non-ideal gas. Marine Chem. 2, 203-215.

Zhang, J., Quay, P.D., Wilbur, D.O., 1995. Carbon isotope fractionation during gaswater exchange and dissolution of CO 2. Geochimica et Cosmochimica Acta 59, 107-114. 